\title{
Long non-coding RNAs: implications in targeted diagnoses, prognosis, and improved therapeutic strategies in human non- and triple-negative breast cancer
}

Rubén Rodríguez Bautista ${ }^{1,2}$, Alette Ortega Gómez ${ }^{1 *} \mathbb{D}$, Alfredo Hidalgo Miranda ${ }^{3}$, Alejandro Zentella Dehesa ${ }^{4}$, Cynthia Villarreal-Garza ${ }^{5}$, Federico Ávila-Moreno ${ }^{6,7}$ and Oscar Arrieta ${ }^{1}$

\begin{abstract}
Triple-negative breast cancer (TNBC) has been clinically difficult to manage because of tumor aggressiveness, cellular and histological heterogeneity, and molecular mechanisms' complexity. All this in turn leads us to evaluate that tumor biological behavior is not yet fully understood. Additionally, the heterogeneity of tumor cells represents a great biomedicine challenge in terms of the complex molecular — genetical-transcriptional and epigenetical—mechanisms, which have not been fully elucidated on human solid tumors.

Recently, human breast cancer, but specifically TNBC is under basic and clinical-oncology research in the discovery of new molecular biomarkers and/or therapeutic targets to improve treatment responses, as well as for seeking algorithms for patient stratification, seeking a positive impact in clinical-oncology outcomes and life quality on breast cancer patients. In this sense, important knowledge is emerging regarding several cancer molecular aberrations, including higher genetic mutational rates, $\mathrm{LOH}, \mathrm{CNV}$, chromosomal, and epigenetic alterations, as well as transcriptome aberrations in terms of the total gene-coding ribonucleic acids (RNAs), known as mRNAs, as well as non-coding RNA (ncRNA) sequences. In this regard, novel investigation fields have included microRNAs (miRNAs), as well as long ncRNAs (IncRNAs), which have been importantly related and are likely involved in the induction, promotion, progression, and/ or clinical therapeutic response trackers of TNBC. Based on this, in general terms according with the five functional archetype classification, the IncRNAs may be involved in the regulation of several molecular mechanisms which include genetic expression, epigenetic, transcriptional, and/or post-transcriptional mechanisms, which are nowadays not totally understood.

Here, we have reviewed the main dis-regulated and functionally non- and well-characterized IncRNAs and their likely involvement, from a molecular enrichment and mechanistic point of view, as tumor biomarkers for breast cancer and its specific histological subtype, TNBC. In reference to the abovementioned, it has been described that some IncRNA expression profiles correspond or are associated with the TNBC histological subtype, potentially granting their use for TNBC malignant progression, diagnosis, tumor clinical stage, and likely therapy. Based on this, IncRNAs have been proposed as potential biomarkers which might represent potential predictive tools in the differentiated breast carcinomas versus TNBC malignant disease. Finally, elucidation of the specific or multi-functional archetypal of IncRNAs in breast cancer and TNBC could be fundamental, as these molecular intermediary-regulator "IncRNAs" are widely involved in the (Continued on next page)
\end{abstract}

\footnotetext{
* Correspondence: ortega.alette@gmail.com

${ }^{1}$ Thoracic Oncology Unit and Laboratory of Personalized Medicine, Instituto

Nacional de Cancerología (INCan), San Fernando \#22, Section XVI, Tlalpan,

14080 Mexico City, Mexico

Full list of author information is available at the end of the article
}

(c) The Author(s). 2018, corrected publication August/2018. Open Access This article is distributed under the terms of the Creative Commons Attribution 4.0 International License (http://creativecommons.org/licenses/by/4.0/), which permits

unrestricted use, distribution, and reproduction in any medium, provided you give appropriate credit to the original author(s) and the source, provide a link to the Creative Commons license, and indicate if changes were made. The Creative Commons Public Domain Dedication waiver (http://creativecommons.org/publicdomain/zero/1.0/) applies to the data made available in this article, unless otherwise stated. 
(Continued from previous page)

genome expression, epigenome regulation, and transcriptional and post-transcriptional tumor biology, which in turn will probably represent a new prospect in clinical and/or therapeutic molecular targets for the oncological management of breast carcinomas in general and also for TNBC patients.

Keywords: Breast cancer, Triple negative, Biomarkers, IncRNA

\section{Background}

The most recent worldwide cancer statistics estimated a total of 2.4 million new cases and 533,000 deaths due to breast cancer (BC) in 2015, thus making it the fifth leading cause of cancer years of life lost between 2005 and 2015 for both sexes. For women specifically, one in 14 will develop $\mathrm{BC}$ between birth and 79 years of age, becoming the leading cause of cancer death for women worldwide [1]. In 2017, 252,710 new breast malignant clinical cases and 40,610 BC deaths were expected to occur in the USA [2].

In addition to the known histopathological classification (tumor cell differentiation status) and TNM (tumor size, lymph node involvement, and metastasis) stage, BC has also been classified on the basis of protein and genetic expression status [3]. In this regard, Perou et al. have defined at least five genetically distinct subtypes with different molecular significance on inter-tumor subtypes [4], but also by intra-tumor heterogeneity in $\mathrm{BC}$ subtypes [5]. Based on the above, intra-tumor heterogeneity has been proposed as having striking morphological, genetic, and behavioral variability explained in part by the cancer stem cells population presence, clonal evolution, and malignancy capacity [6, 7]. Additionally in $\mathrm{BC}$, other molecular-genetic alterations exist based on well-known non-coding RNAs (ncRNAs), including micro-ncRNAs (microRNAs) and long-ncRNAs (lncRNAs), both of which have been identified and histopathologically associated to $\mathrm{BCs}$, as triple-negative $\mathrm{BC}$ (TNBC) $[8,9]$, but particularly some lncRNAs, in others as LOC339535 also named LINK-A, have functionally been associated to TNBC malignancy with poorer prognosis and progression-free survival in TNBC patients [10], as well as for HOTAIR, which has been involved in promoting or increasing malignancy in TNBC patients, compared with non-TNBC patients, probably representing a new target therapy in TNBC [11].

TNBC as a heterogeneous group of breast tumors has been characterized by the lack of expression of hormone receptors, namely estrogen receptor alpha (ER- $\alpha)$ and progesterone receptor (PR), with a low expression of receptor tyrosine kinase ErbB2 (also known as HER2/neu). In TNBC, additional molecular-genetic features have been identified including BRCA1/2 mutation frequency (11.2-20.0\%) [12-15], which may be higher in approximately $20-40 \%$, according to the ethnic origin [16], furthermore including additional molecular deficiencies, in others as some frequent somatic mutations on TP53 (62\%) and PIK3CA (10\%) [12, 13].

In addition to the mutation status, TNBC tumors also display alterations on the genetic copy number variations, genetic expression levels, and patterns, which have been associated with basal-like tumors including a high proportion of the basal histological BC subgroup (70-80\%) [17]. Besides TNBCs exhibiting poor survival rates due to their highly aggressive and metastatic capacities, they are associated with higher recurrence behavior in local and distant lymph nodes and have higher proliferative rates [18-20], probably explained in part by the genetic-molecular aberrations.

Approximately, on average, 12 to $24 \%$ of women diagnosed with BC correspond to the TNBC subtype. TNBC represents a subgroup of particular interest, since it generally affects young women and tends to have a poor response to standard chemotherapy [21-23].

In TNBC, the US Food and Drug Administration (FDA) and the European Medicines Agency (EMA) have not yet approved a specific targeted agent for clinical treatment in the adjuvant, neoadjuvant, or metastatic settings. Currently, radiotherapy and a combination of chemotherapeutic agents like anthracyclines, alkylating agents, taxanes, or platinum salts are used for treating TNBC patients [24]. Thus, efficient targeted therapeutic regimens are urgently needed in TNBC for clinical management, since currently these patients have low rates of disease-free survival (DFS), overall survival (OS), and 5-year survival, in addition to a low survival 12-18 months after distant recurrence $[25,26]$.

TNBC tumors have been characterized by high levels of genetic instability, with a median of 1.7 (range 0.16-5.23) mutations/Mb $[27,28]$, and feature complex patterns of copy number gains and losses throughout the genome [29]. Epigenetically TNBCs are characterized by extensive hypomethylation, which leads to increased genome-wide instability [30]. Recently, Mathe et al. have shown that the changes in the epigenome, based on DNA methylation levels, are associated with tumor progression in TNBC [31-33].

Recent reports have shown that lncRNAs are involved in almost all human biological processes including transcriptional regulation or interference, telomere maintenance, epigenetic mechanisms modulation, imprinting, post-transcriptional and translational control, structural 
organization, cellular differentiation, embryo development, and pathological dysfunctions as well as non-malignant diseases, using redundant DNA, RNA, and/or protein-binding mechanisms, according to particular cases [34-36]. As it occurs for other malignant diseases, lncRNAs have been involved in the tumorigenic promotion and progression processes leading to $\mathrm{BC}$ development and prognosis [37].

Liu et al. proposed a TNBC classification based on mRNA coding genes and lncRNA expression profiles. This new classification could offer a more robust data matrix to establish a molecular stratification bioinformatics-algorithm that clarifies knowledge of molecular subtypes and establishes subtype-specific targets [38]. Additionally, genome-wide association studies on cancer have revealed that more than $80 \%$ of cancer-associated single-nucleotide polymorphisms occur in non-coding genetic regions. This suggests that a significant fraction of the genetic etiology of $\mathrm{BC}$ could be related to lncRNA expression profile and functionality [39]. Also, research involving genetic sequence control (promoters vs. enhancers) is necessary, in order to explain why, how, and where lncRNAs are expressed in human homeostasis as well as during a pathologic process [40].

In recent years, therapeutic strategies for TNBC have recorded a high number of failures in the development of chemical agents, due to the fact that recently it has been proposed to include molecular wide studies to identify additional potential biomarkers, as well as genetic-epigenetic targets, probably involved. In this regard, epigenetic targeted pathways have widely been proposed as pharmacological strategies, among these histone deacetylase inhibitors (HDACis) alone and/or in combination strategies have promising activity in TNBC-targeted treatments. Therefore, future research should be focusing on the personalized approach, which will benefit more from each kind of epigenetic agents, including panobinostat, vorinostat, and entinostat [41]. In addition, by identifying reliable treatment biomarkers, such as lncRNAs, which are implicated in epigenetic mechanisms through the recruitment of the chromatin modification complexes, in other proteins based on the polycomb repressor complex-2 (PRC2) and/or LSD1/ CoREST (REST co-repressor) REST complexes, involved in the histone repressor (H3K27me3) versus activation (H3K4me2/3) code, as it has been previously described for the lncRNA HOTAIR, suggesting a scaffold functionality archetype [42], as IncRNAs have functionally been classified by five archetypes (described in Fig. 1).

In brief, the present review summarizes the current knowledge regarding lncRNA expression patterns and probable functional association with their role in BC biology and as expressed molecular biomarkers, potentially involved as therapeutic targets. In this regard, we aim to generate a systematic and deep understanding of tumor biology of TNBC, so clinicians will, in the near future, be able to offer tailored treatments in accord to the lncRNA stratification and/or specific lncRNA expression patterns in potentially different patient subgroups in $\mathrm{BC}$ and $\mathrm{TNBC}$.

\section{Targeted therapy efficacy in the TNBC treatment: probable IncRNAs involved}

Due to the lack of knowledge on molecular targets, chemotherapy is the only available systemic treatment for TNBC and therefore adjuvant chemotherapy is recommended for TNBC operable tumors with stages I-III $[43,44]$. However, systemic therapy before surgery, neoadjuvant chemotherapy (NAC), is the most appropriate approach for patients with locally advanced $\mathrm{BC}$ with the objectives to improve surgical options (resectability and breast conservation techniques), determine in vivo tumor sensitivity to treatment, and improve long-term survival outcomes with the pathological complete response (pCR) as an informative biomarker of those parameters [45-48]. Even with what is deemed as a poor overall survival, it is evident that subsets of TNBC patients respond better to standard care using chemotherapy combinations, and when pCR after NAC is achieved; excellent long-term survival is expected [49]. Nevertheless, a substantial proportion (30-40\%) of patients with early-stage TNBC develop metastatic disease [50].

In this sense, the triple-negative paradox on TNBC patients is mainly driven by a subgroup of cells on the bulk tumor with residual disease after NAC [50]. For this reason, the search for new biomarkers would allow the prediction of a group of TNBC patients who would better respond to standard chemotherapy, thus eliminating the need to administer unnecessary, highly toxic, and costly chemotherapy treatments in patients who might benefit from more personalized treatments.

Researchers have proposed new targeted therapies based on results from clinical trials in an attempt to improve the outcome of TNBC patients. Retrospective analyses and previous trials have shown striking $\mathrm{pCR}$ rates in patients with high BRCA1 mutation rates (between 72 and $90 \%$ ) with a single neoadjuvant treatment using DNA crosslinking platinum salts (e.g., cisplatinum) [51, 52]. For example, TNBC patients with positive $B R C A$ mutations treated with carboplatin have better response rates compared to those treated with docetaxel monotherapy [53]. Other studies have evaluated poly (ADP-Ribose) polymerase (PARP) inhibitors either alone or in combination with cytotoxic treatment. However, response to these schemes is limited to patients with BRCA-mutated BC $[54,55]$.

Likewise, hyper-activation of the PI3K/AKT signaling pathway is associated to oncogenic alterations in TNBC, 

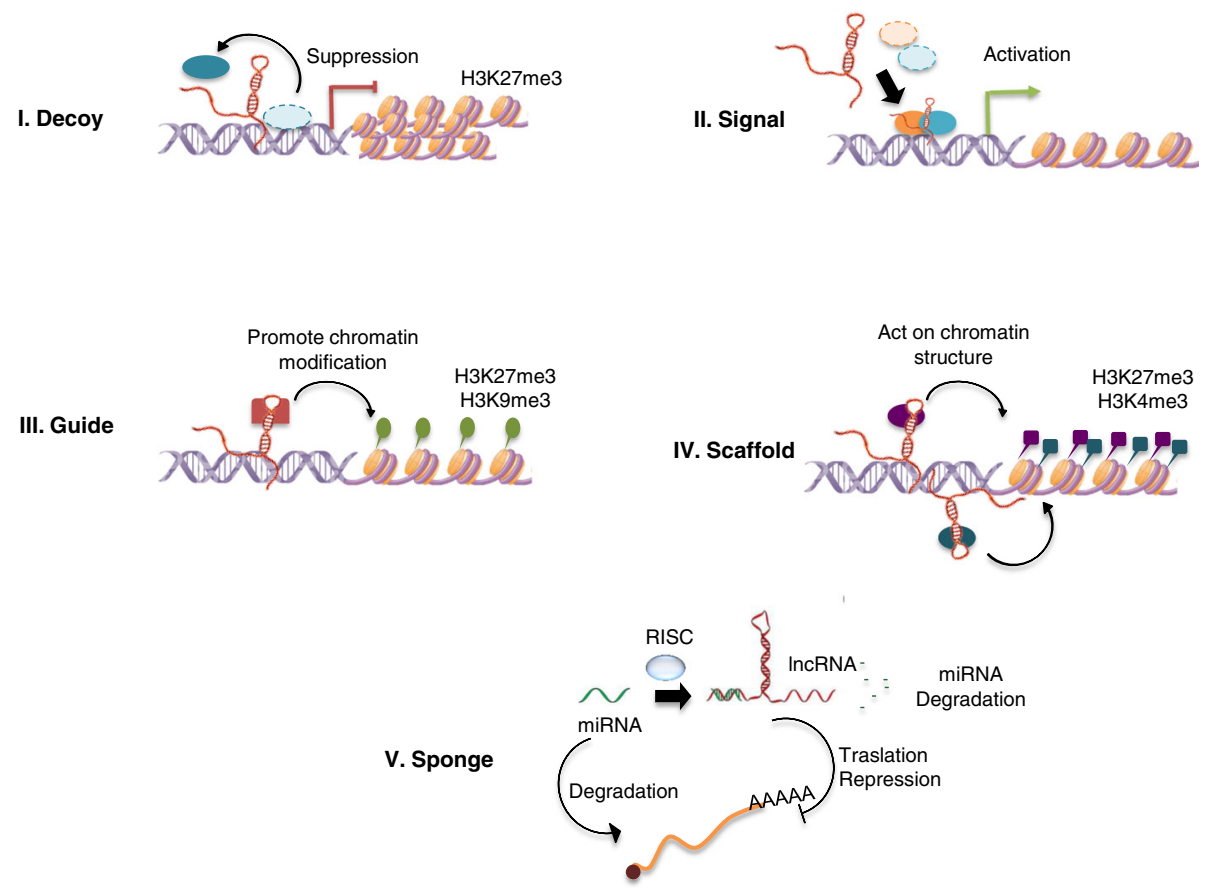

Fig. 1 Proposed five functional archetypes for the IncRNA mechanisms. 1. Decoys: IncRNAs can titrate away transcription factors and other proteins away from chromatin, or titrate the protein factors into nuclear subdomains. 2. Signals: IncRNAs expression can faithfully reflect the combinatorial actions of transcription factors (colored ovals) or signaling pathways to indicate gene regulation by space and time. 3. Guides: IncRNAs may recruit chromatin-modifying enzymes to gene-promoter targets, either in Cis (near the genetic region of the IncRNA transcription) or in Trans into distant target genes. 4. Scaffolds: IncRNAs may bring together multiple proteins to conform ribonucleoprotein complexes. The IncRNA-RNP may act on chromatin as illustrated to affect histone code modifications. In other instances, the IncRNA scaffold is structural and stabilizes nuclear structures or signaling complexes 5. Sponge: IncRNAs that by complementarity of bases succeed in matching or sequestering sequences of small non-coding RNAs, such as miRNAs, are controlling bioavailability of miRNAs, vs. IncRNAs themselves, with the functional biological repercussions at cellular or physiological level. RNA-induced silencing complex RISC

occurring in approximately $10 \%$ of patients [56]. Activating PIK3CA mutations are the most frequent mutations in TNBC. Other alterations in this pathway include loss of tumor suppressor phosphatases inositol polyphosphate 4-phosphatase type II (INPP4B), loss of phosphatase and tensin homolog (PTEN), AKT amplification, and AKT3 translocation [57-59]. In this regard, several studies have demonstrated the benefits of using serine/threonine kinase AKT inhibitors like ipatasertib in TNBC [37, 38, 60].

On the other hand, growth factor receptors are overexpressed in TNBC, including epidermal growth factor receptor (EGFR) and vascular endothelial growth factor receptor (VEGFR) [61-66]. Multiple signaling pathways, such as PI3K/AKT, mitogen-activated protein kinase (MAPK), and Wnt/B-catenin are activated by EGFR and, in turn, enhance proliferation, survival, invasion, and metastasis of cancer cells [67]. Expression of EGFR is frequently associated with TNBC and has been viewed as a promising therapeutic target. Unfortunately, the therapeutic efficacy of EGFR-targeting agents in BC has been disappointing $[68,69]$. A recent report showed that combined treatment with lapatinib, a dual inhibitor of EGFR and ErbB2/HER2, and imatinib, a c-ABL inhibitor, resulted in synergistic growth inhibition in a panel of EGFR/ErbB2-expressing BC cells, including the TNBC cell line MDAMB-468 [70].

Recently, studies on fibroblast growth factor receptor (FGFR) have shown that 9\% of TNBC with FGFR1 (4\%) and FGFR2 amplifications, treated with FGFR blockers like lucitanib (FGFR1-amplification) and JNJ-42756493 (FGFR translocation or FGFR activating mutation), provide clinical benefits [51, 71-73]. Approximately 10 to $15 \%$ of TNBC express the androgen receptor (AR), and several studies have reported pathological response benefits when targeting this receptor. Bicalutamide, enzalutamide, and orteronel are all oral non-steroidal anti-AR, on that the most recent clinical trials for TNBC are shown in Table $1[72,74-76]$.

As previously described, TNBC is a heterogeneous disease, and even though a high number of targeted therapies have been clinically tested, this has not yet translated into a substantial clinical benefit for TNBC patients. Hence, it is necessary to identify highly sensible biomarkers for a better stratification and treatment of these patients. Recently, long non-coding RNAs (lncRNAs) have been reported to drive many important 


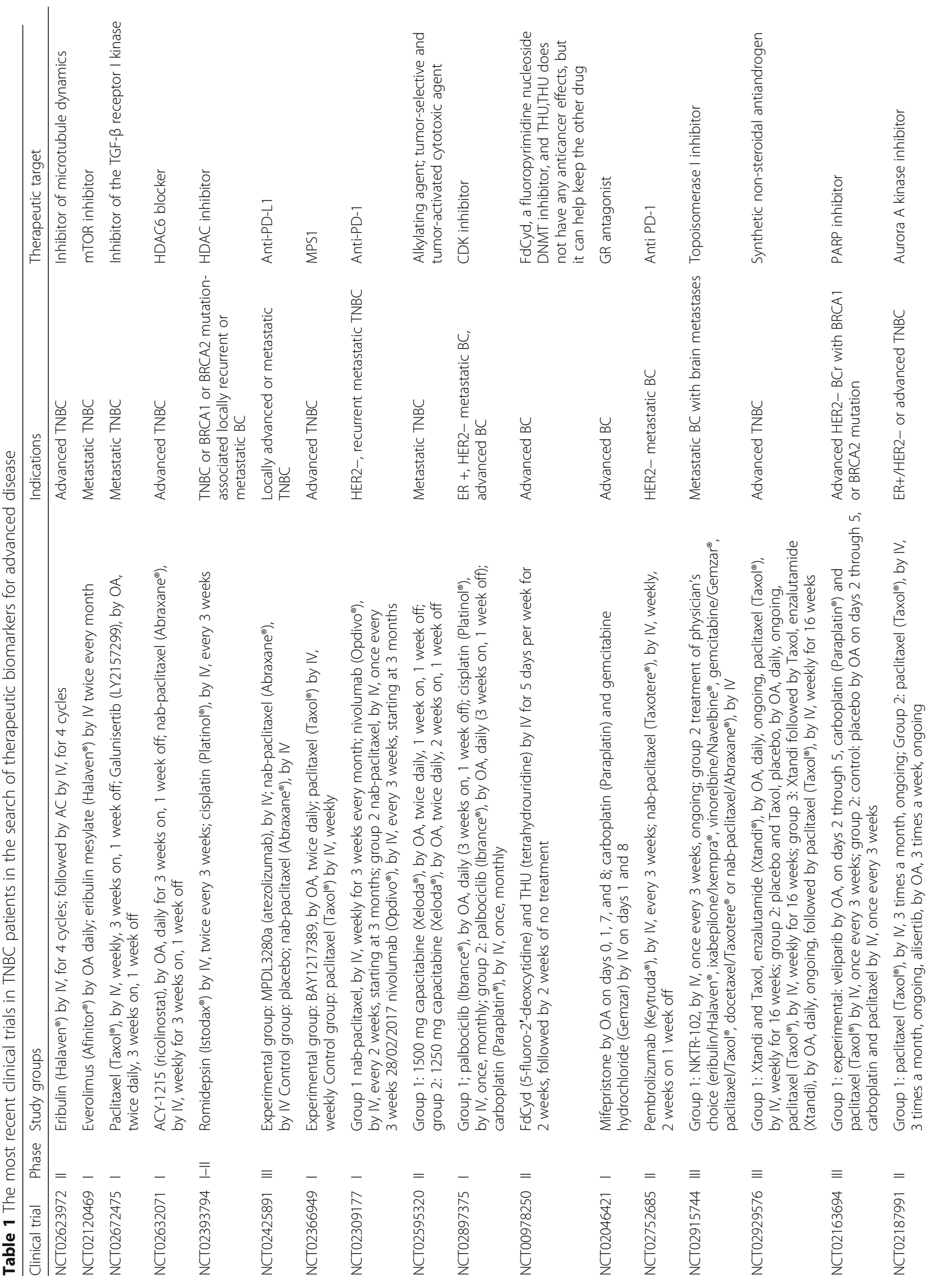




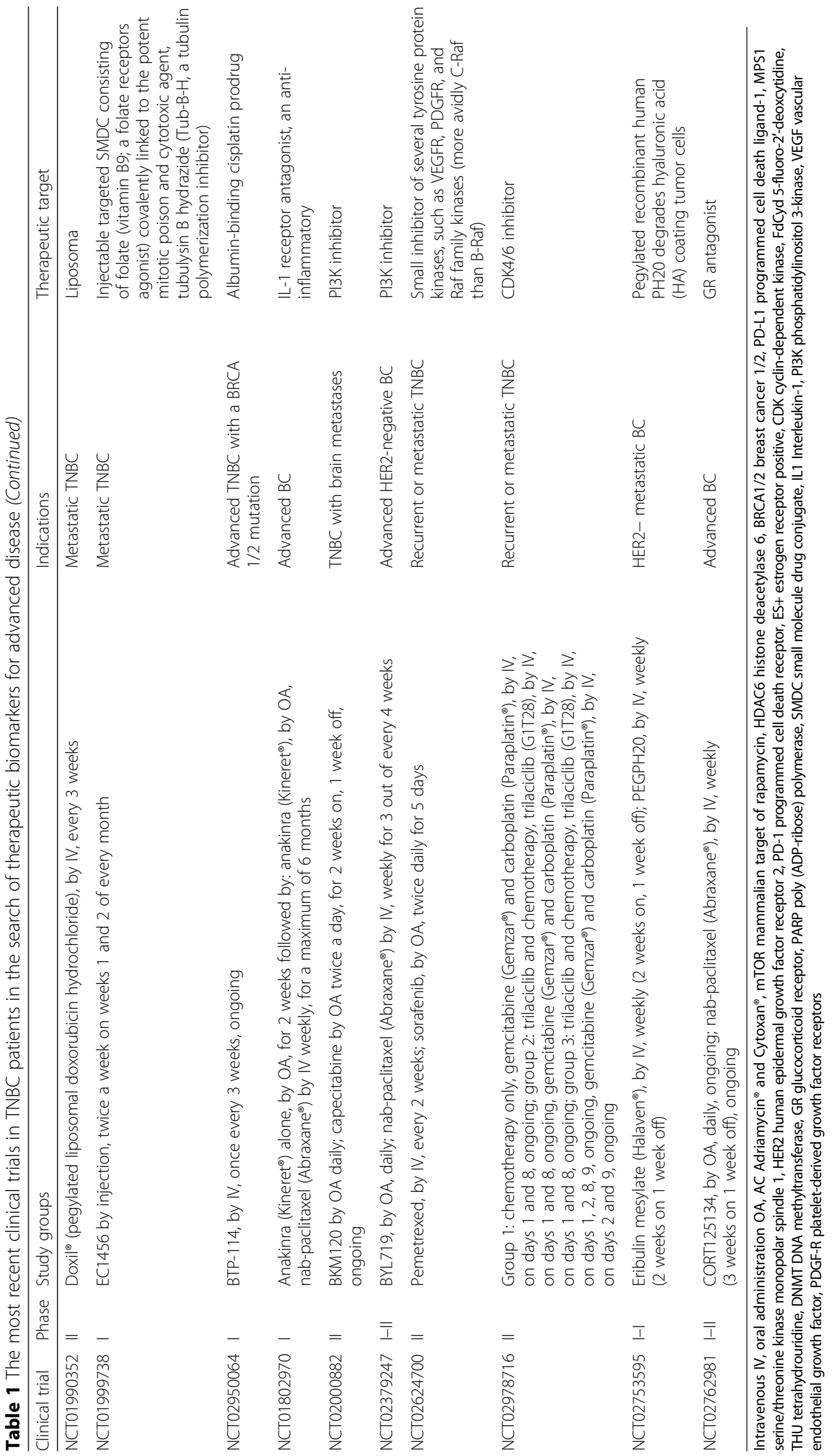


cancer phenotypes through their interactions with other cellular macromolecules [77, 78]. To date, it has been strongly proposed that a deeper functional understanding of lncRNAs will provide novel insights into the molecular mechanism of cancer. As such, lncRNAs are likely to serve as the basis for many clinical applications in oncology [79], like potential biomarkers for diagnosis or therapy targets for clinical treatment of TNBC, as we discuss next.

\section{IncRNAs: molecular mechanisms and potential therapeutic functionality}

Protein-coding gene sequences represent a minority (less than $2 \%$ ) of the human genome sequences; in contrast, the majority are represented by protein non-coding genome sequences, such as non-coding RNAs (ncRNAs) [80]. The ncRNAs can be divided into two categories: house-keeping ncRNAs (tRNA, rRNA, etc.) and regulatory ncRNAs (miRNA, IncRNA, piRNA, etc.) [81]. LncRNAs are regulatory ncRNAs with at least $200 \mathrm{nu}$ cleotides long (nt) that do not encode any protein [82].

Based on the genomic location sites of the lncRNA transcripts and their neighboring relation with the protein-coding genes, IncRNAs can be divided into five categories: (1) sense lncRNAs, which overlap one or more exons of transcripts on the same strand; (2) antisense lncRNAs, which overlap one or more exons of another transcript on the opposite strand; (3) bidirectional IncRNAs, which are located on the opposite strand from the neighboring exon whose transcription orientation has been identified at less than 1000 base pairs; (4) intronic lncRNAs, which are structurally located within another intron of another transcript; and (5) intergenic lncRNAs, which interact within the genomic interval between two genes [83]. In addition, many known lncRNAs have been identified intracellularly either within the cytosol and/or between the nuclear and cytoplasm compartments [84]. According to recent studies, the human transcriptome contains up to 16,000 lncRNAs, frequently spliced and polyadenylated, whose non-coding genes are mainly transcribed by the RNA polymerase II [85].

Raised evidence supports that lncRNAs have potential, diverse, and deep functional roles at the nucleus level, which include acting as a positive (activation) mechanism of the transcriptional regulation, as well as their involvement in the inactivation of epigenetic mechanisms (Eg., X-chromosome inactivation), heterochromatin conformation, telomere maintenance, and pluripotency capacity modulation and also have been seen to be involved in cancer development [86-88].

It has become increasingly important to link clinical correlation studies and experimental evidences, which has suggested that lncRNAs contribute to tumor promoting, progression, and metastasis for different malignant diseases through several cellular processes, ranging from transcriptional (cis/trans) and post-transcriptional regulation mechanisms in cell cycle distribution control and cell differentiation to epigenetic modification mechanisms [89-92]. LncRNAs modulate gene transcription by rearranging chromatin via chromosomal looping and by affecting the binding of transcription factors. LncRNAs also affect miRNA functions by controlling pre-mRNA splicing or as miRNA sponges. Recently, accumulating evidence indicates that there is aberrant expression of IncRNAs in many cancer types [93]. An increasing number of studies have demonstrated that a number of lncRNAs are not transcriptional noise, but have important functions, such as regulating gene expression at various molecular levels, including RNA, miRNA, DNA, and proteins, playing important roles in RNA translation and cytoplasmic protein trafficking [94]. Few studies like Yang et al. have focused on how lncRNA genes themselves are regulated by different transcripts activating regulatory regions of IncRNAs [95].

Other studies have indicated that altered expression levels of IncRNAs are associated with human diseases, including BC. Examples include the lncRNAs H19, HOTAIR (HOX transcript antisense RNA), and UCA1 (urothelial cancer associated 1, non-protein coding), which silence tumor suppressor genes. Likewise, lincRNA-p21 mediates global gene repression in the p53 response, while GAS5 plays a tumor suppressor role [96-100]. Another specific example is CYTOR (cytoskeleton regulator RNA), which plays a role in $\mathrm{BC}$, regulating genes involved in the EGFR/mammalian target of the rapamycin pathway and is required for cell proliferation, cell migration, and cytoskeleton organization [101]. Other IncRNAs have been associated with drug resistance to standard BC treatment. Examples include ARA-lncRNA (adriamycin resistance associated), which provided novel insights into adriamycin resistance. Breast cancer antiestrogen resistance 4 (BCAR4) is related to tamoxifen resistance and could also sensitize $\mathrm{BC}$ cells to lapatinib. Lastly, CCAT2 (colon cancer-associated transcript 2) may be downregulated by chemotherapy with 5-FU, blocking different pathways involved with cell migration [102-105]. Other potential targeted lncRNA for breast cancer treatment include SPRY4-IT1 and PANDAR $[8,100]$. However, recent studies have revealed that the dysregulation of lncRNAs that are known to be associated with human disease is often due to the aberrant expression of transcription factor inducers that could initiate oncogenic mechanisms by feedback complexes [8].

Recently, $\mathrm{Lv}$ et al. found IncRNAs as ANRIL, HIF1A-AS2, and UCA1 expression was significantly 
increased in plasma of patients with TNBC [106], suggesting their use as TNBC-specific diagnostic biomarkers and/ or molecular prognostic predictors [106, 107].

\section{LncRNAs in TNBC: biology and their potential therapeutic for clinical oncology}

Non-coding sequences have a crucial participation for genetic expression regulation or modulation of several genes implicated in BC. However, it remains to be described a total pattern or profile expression of the long non-coding RNAs for the TNBC subgroup that could be implicated in the invasiveness malignity of these tumors.

First at all, Shen et al. identified 1758 lncRNAs and 1254 mRNAs with significant expression differences in TNBC vs. normal adjacent tissue based in microarray analysis [108]; subsequently, Yang et al. and other researcher groups have been working on the identification and validation of the differential expression of lncRNAs by RNA massive sequencing methods (RNA-seq) [9, 79], as well as, more recently single-cell RNA sequencing (scRNASeq) that allows the quantification of transcript expression profiles for individual cells in a cellular population of solid tumor [107, 109]. Following, on 2015,
Chen et al. discovered and validated a set of novel aberrant lncRNA profile expressed in TNBC, suggesting that deregulated lncRNA pattern may play a role in the developmental and progression of TNBC (Table 2).

An interesting study has suggested a lncRNA candidate named LINC00993, which is both considerably deregulated in TNBC and associated with the ER and ANKRD30A gene expression [110]. ANKRD30A (also known as NY-BR-1 or B726P) encodes a DNA-binding transcription factor previously detected in well-differentiated ER-positive and HER2-negative BC tumors [111]. Also, ANKRD30A has been identified as a $\mathrm{BC}$ antigen in disseminated tumor cells (DTCs), and is currently one of the most used DTC biomarkers, and a potential target for BC immunotherapy, so the correlated expression between lncRNA LINC00993 and ANKRD30A gene has supported strong evidence that ANKRD30A gene expression may be epigenetic-target of the IncRNA LINC00993; however, more studies are needed in this regard [112-114]. Some lncRNAs have been proposed as competitive endogenous RNA (ceRNA) for short non-coding RNA (miRNAs). LincRNA-RoR (regulator of reprogramming) is

Table 2 Main IncRNAs associated with triple-negative breast cancer

\begin{tabular}{|c|c|c|c|}
\hline Author & IncRNA & Alteration in TNBC & Function/characteristics \\
\hline $\begin{array}{l}\text { Augoff et al. } \\
2012[127]\end{array}$ & LOC554202 & Upregulated & $\begin{array}{l}\text { MIR31 host gene, regulates proliferation and migration in breast cancer cells } \\
\text { and promotes hypermethylation of miR31 in TNBC }\end{array}$ \\
\hline \multirow[t]{4}{*}{$\begin{array}{l}\text { Chen et al. } \\
2015[110]\end{array}$} & LINC00993 & Upregulated & $\begin{array}{l}\text { Associated with the expression of the estrogen receptor and the expression } \\
\text { levels of ANKRD30A }\end{array}$ \\
\hline & TCONS_12_00002973 & Upregulated & Associated with the expression of the estrogen receptor. \\
\hline & TCONS_12_00003939 & Upregulated & Associated with the expression of the estrogen receptor. \\
\hline & TCONS_12_00002974 & Upregulated & Associated with the expression of the estrogen receptor. \\
\hline $\begin{array}{l}\text { Eades et al. } \\
2015 \text { [118] }\end{array}$ & lincRNA-RoR & Upregulated & $\begin{array}{l}\text { Prevents the core TFs from miRNA-mediated suppression in self-renewing } \\
\text { human SC }\end{array}$ \\
\hline \multirow[t]{2}{*}{$\begin{array}{l}\text { Wang et al. } \\
2015 \text { [119] }\end{array}$} & HOTAIR & Upregulated & $\begin{array}{l}\text { Regulates chromatin state. It is required for gene silencing of the HOXD locus } \\
\text { by PRC2, highly expressed in metastatic breast cancers. High levels of expression } \\
\text { in primary breast tumors are a significant predictor of subsequent metastasis } \\
\text { and death }\end{array}$ \\
\hline & MALAT1 & Upregulated & $\begin{array}{l}\text { Alternative splicing, nuclear organization, epigenetic modulating of gene expression, } \\
\text { and a number of evidences indicate that MALAT1 also closely relate to various } \\
\text { pathological processes, ranging from diabetes complications to cancer. It regulates } \\
\text { the expression of metastasis-associated genes, with proliferation, motility, and } \\
\text { apoptosis evasion }\end{array}$ \\
\hline \multirow[t]{2}{*}{$\begin{array}{l}\text { Lin et al. } \\
2016[10]\end{array}$} & $\begin{array}{l}\text { LINK-A (also known as } \\
\text { LOC339535 and NR_015407) }\end{array}$ & Upregulated & $\begin{array}{l}\text { Is an RNA of binding to kinases that phosphorylate HIF } 1 \text { alpha in different sites to } \\
\text { the canonical ones in human cancer }\end{array}$ \\
\hline & RMST & Downregulated & Tumor suppressor \\
\hline $\begin{array}{l}\text { Yang et al. } \\
2016[79]\end{array}$ & LINC01234 & Up/downregulated & Oncogene/tumor suppressor \\
\hline \multirow[t]{2}{*}{$\begin{array}{l}\text { Koduru et al. } \\
2017 \text { [9] }\end{array}$} & Inc-DNAJC16 & Upregulated & $\begin{array}{l}\text { Belonging to the DnaJ heat shock protein family, functions in protein translation, } \\
\text { translocation and degradation }\end{array}$ \\
\hline & Inc-PURA & Upregulated & $\begin{array}{l}\text { It is a sequence-specific, multi-functional single-stranded-DNA/RNA-binding protein } \\
\text { and RNA-binding protein which can act as a transcriptional activator and repressor }\end{array}$ \\
\hline
\end{tabular}

IncRNA, long non-coding RNA; ANKRD30A, Ankyrin repeat domain 30A; TFs, transcription factors; miRNA, microRNA; PRC2, polycomb repressive complex 2; HIF-1a, hypoxia-inducible factor 1 alpha; lincRNA-RoR, long intergenic non-protein coding RNA, regulator of reprogramming; HOTAIR, HOX transcript antisense RNA; MALAT1, metastasis-associated lung adenocarcinoma transcript 1; LINK-A, long intergenic noncoding RNA for kinase activation; RMST, rhabdomyosarcoma 2-associated transcript 
a lincRNA-RoR as miRNA inhibitor
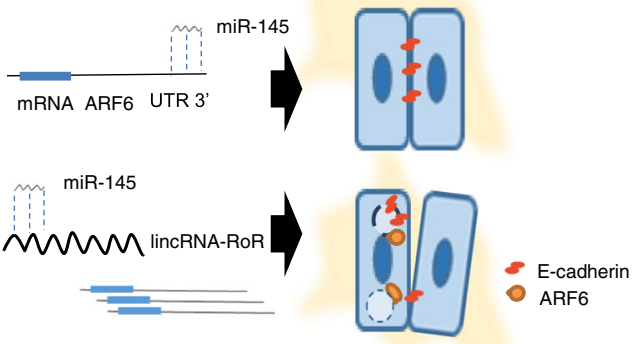

b competitive endogenous RNAs (ceRNA)
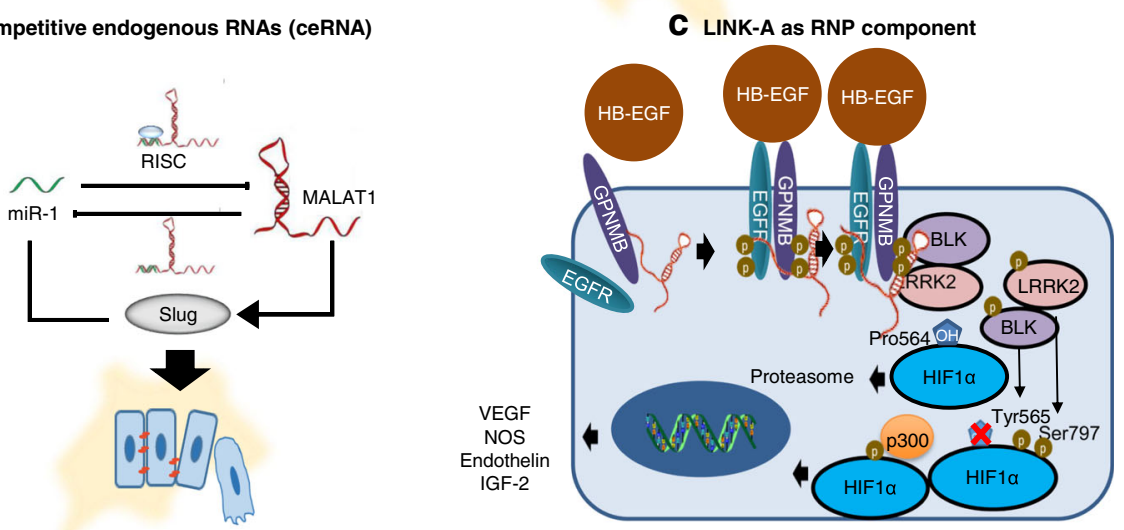

Fig. 2 A molecular mechanism model for IncRNAs involved in the tumorigenesis of human TNBC. a lincRNA-RoR as a miR-145 inhibitor (oncogene miRNA). b MALAT1 as a competitive endogenous RNA of miR-1 (tumor suppressor miRNA). $\mathbf{c}$ LINK-A as a component of ribonucleoprotein complexes, example shows the regulations of HIF1a pathway. ARF6 ADP-ribosylation factor 6, UTR 3' untranslated region 3, RISC RNA-induced silencing complex, HB-EGF heparin-binding EGF-like growth factor, EGFR epidermal growth factor receptor, GPNMB transmembrane glycoprotein NMB, BLK B lymphocyte kinase, LRRK2 leucine-rich repeat kinase 2, HIF1a hypoxia-inducible factor 1-alpha, vascular endothelial growth factor VEGF, iNOS inducible nitric oxide synthase, IGF-2 insulin-like growth factor 2, RNP ribonucleoprotein

upregulated in pluripotent cells (shown in Fig. 2a) [115], where it functions as ceRNA for miR-145, thereby protecting pluripotency factors from miR-mediated silencing, leading to loss of mature miR-145 expression [116]. Recently, Eades et al. found that in TNBC, loss of miR-145 promotes tumor cell invasion. This is mediated through ARF6 overexpression, a protein implicated in tumor invasion through disturbance of cell-cell adhesion by endocytose E-cadherin. In this case, lincRNA-RoR generates a competitive inhibition of miR-145, which alters ARF6 expression. The authors also reported an overexpression of lincRNA-RoR in lymph node positive tumors of TNBC patients and reported the first ceRNA network in human cancer (shown in Fig. 2a) [117, 118].

The expression of other lncRNAs, like HOTAIR, has been shown to enhance the growth and metastasis in xenograft mammary tumors [97]. Wang et al. showed that HOTAIR expression is closely correlated with primary TNBC tumor tissues and demonstrated that HOTAIR expression is transcriptionally repressed by the combined treatment of lapatinib plus imatinib, the first inhibiting EGFR and ErbB2/HER2, and the second a
c-ABL inhibitor through $\beta$-catenin-binding sites LEF1/ TCF4 [119]. In another study, Jin et al. showed that metastasis-associated lung adenocarcinoma transcript 1 (MALAT1) lncRNA exerts its oncogenic activity by interacting with miR-1. MALAT1 was found upregulated in TNBC tissues and is associated to tumor growth and metastasis, as well as poor overall survival. Downregulation of MALAT1 increased the expression of microRNA-1 (miR-1), while overexpression of miR-1 decreased MALAT1 expression. In this sense, MALAT1 exerted its function through the miR-1/slug axis and therefore MALAT1 may be a target for TNBC therapy (shown in Fig. 2b) [120]. Recently, Lin et al. showed that the long intergenic non-coding RNA for kinase activation (LINK-A) is critical for growth factor-induced normoxic signaling pathway by recruiting breast tumor kinase (BRK) activated together with leucine-rich repeat kinase 2 (LRRK2). The latter phosphorylates hypoxia-inducible factor 1-alpha (HIF1 $\alpha)$ at Tyr565 and Ser797. The phosphorylation at Tyr565 inhibits hydroxylation at the adjacent Pro564, which prevents HIF1 $\alpha$ degradation under normoxic conditions. Ser797 
phosphorylation facilitates HIF1 $\alpha-p 300$ interaction, leading to activation of HIF1 $\alpha$ target genes upon heparin-binding EGF-like growth factor (HB-EGF) stimulation. Importantly, both LINK-A expression and activation of the LINK-A-mediated normoxic HIF1 $\alpha$ signaling pathway could serve as a therapeutic strategy in TNBC (shown in Fig. 2c) [121]. Downregulation of lncRNAs has also been shown to be associated with worse clinical outcomes. Such is the case of rhabdomyosarcoma 2-associated transcript (RMST), which functions as an oncogene and whose expression has been correlated to a lower overall survival [79].

\section{Potential IncRNAs as probable epigenetic biomarkers in TNBC}

Nuclear lncRNAs may act as an epigenetic regulator or a guide by recruiting chromatin modification factors to cytogenetic locus, but particularly at gene regulatory/ promoter sequences (shown in Fig. 1). As scaffold archetype, nuclear lncRNAs bring together multiple proteins to conform ribonucleoprotein (RNP) complexes. Such lncRNA-RNP complexes can either affect histone modifications or stabilize signaling complexes or nuclear structures [9], as decoy, signaling, and/or guide functional archetypes, as well (Fig. 1).

Recently, Rahman et al. have identified lncRNA lnc00673 (ERRLR01) as a marker of overall survival (OS) in BC patients. Specifically, ERRLR01 levels were elevated in TNBC as compared with BC ER $\alpha$-positive patients. LncRNA ERRLR01 expression levels were also inversely correlated with $\mathrm{BC}$ survival for all $\mathrm{BC}$ patients, suggesting that ERRLR01 is modulated by hormone signaling in BC [122]. Following this observation, Bamodu et al. showed that metastatic BC cell lines exhibited increased expression levels of lysine-specific demethylase 5B protein (KDM5B) and lncRNA MALAT1, suggesting a functional association. However KDM5B silencing in TNBC cells has been correlated with the upregulation of hsa-miR-448 and led to suppression of MALAT1 expression with a decreased migration, invasion, and clonogenic capacity in vitro, as well as poorer overall survival in vivo (shown in Fig. 3 a) [123]. On the other hand, some miRNAs (microRNAs) that control gene expression by post-transcriptional regulation have been shown to be transcribed as part of host genes. For example, miR-31 is a tumor suppressor-miRNA which is transcribed from the first intron of a host gene LOC554202, on human chromosome 9 [124]. On the other hand, some short non-coding RNA mediate oncogenic processes, such as miR-31, which regulates a group of pro-metastatic target genes, including WAVE3, RhoA, Radexin, and several integrin subunits that regulate key steps in the invasion metastasis cascade $[125,126]$. Augoff et al. in 2012 identified a major CpG island upstream of the miR-31 locus, which also spans the first exon of LOC554202, suggesting an epigenetic regulation

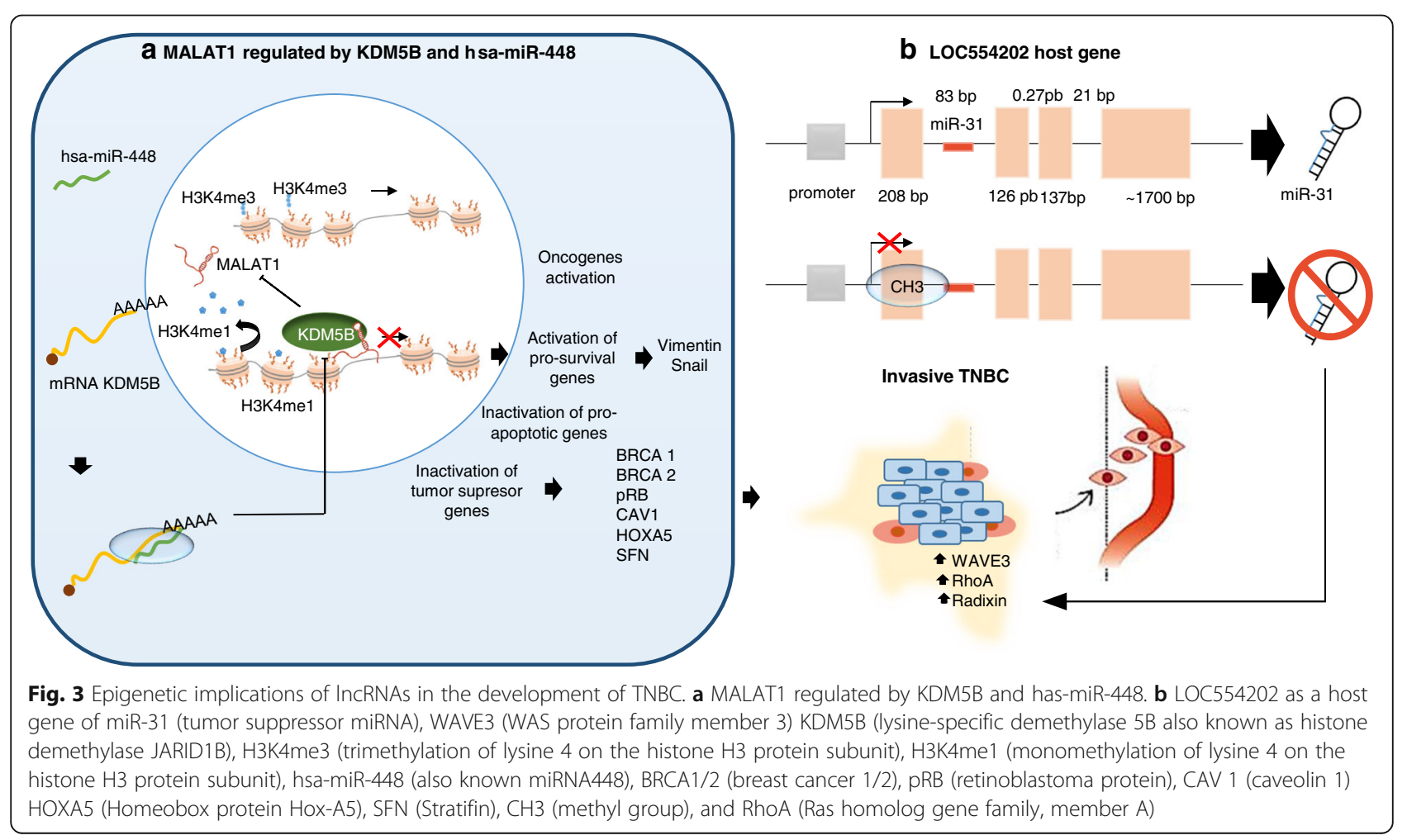


by methylation of both miR31 and the host gene in basal TNBC compared to luminal BC cell lines (shown in Fig. 3 b) [127].

\section{Perspectives: IncRNAs as potential therapeutic targets}

As we have shown, lncRNAs play several roles in TNBC, but their biological participation is not yet fully understood. Some important advances have been reached, such as the study by Wang et al. which describes different expression patterns of lncRNAs in TNBC vs. non-cancer tissue. We believe that this opens new ideas for functional studies on lncRNAs that have not yet been totally defined as modulators of mRNA coding genes [119]. The lack of complete patterns impedes the development of new TNBC molecular targets, as well as, new-targeted drugs, which could specifically target functional lncRNAs.

However, it would be a fascinating and novel therapeutic strategy. On that recently, Xia et al. designed one oligonucleotide with some chemical modifications which improve its half-life in serum, this molecule antagonizes the function of one tumorigenic IncRNA named ASBEL [128]; in this regard, they have proposed it as a new field of research of potential therapeutic tools for the treatment of TNBC, also named gene therapy.

Notably, IncRNAs could be detected in human bodily fluids, acting as biomarkers. Chen et al. provided useful information for exploring potential therapeutic targets for TNBC [110]. Recently, studies have demonstrated that lncRNA expression could be regulated by conventional chemotherapy agents like tyrosine kinase receptors (TKRs) and non-TKRs by targeting multiple genes at the same time through unknown mechanisms [120]. More studies that strongly focus on molecular mechanisms are needed in order to improve our understanding of how these FDA-approved chemotherapeutic agents for malignant neoplasms exert regulatory action through epigenetic mechanisms on TNBC.

We also know the existence of lncRNA domains upon chromatin structure, where it plays a critical role in the development and/or progression of TNBC disease. Shen et al. explained that chromosome 1 and 10 are the major domains of dysregulation of lncRNAs and mRNA expression, both regulated by lncRNAs through an unknown mechanism [108]. Our research group suggests co-localization of lncRNAs that dictates oncogenic decisions during the development of aggressive TNBC. Several lncRNAs are implicated on hormonal resistance therapy [100]. While some platforms like Oncotype and MammaPrint help medical staff to better identify which patients will respond to standard chemotherapy and have a better prognosis, here, we take into consideration co-expressed mRNAs/lncRNAs that could identify
TNBC patients that could benefit from personalized pharmacological treatments. LncRNAs as biomarkers and their associated genetic-epigenetic and transcriptional mechanisms in co-expression patterns of mRNA coding genes open new insights for gene expression control, and epigenetic events that could explain pathophysiology and/or pharmacological actions for clinical diagnosis, treatment response, and prognosis of TNBC patients.

\section{Conclusions}

Perhaps we are approaching an era of personalized therapies for TNBC patients, as was initially idealized by Lehmann et al. who elucidated the TNBC heterogeneity $[54,129,130]$. These therapies, probably will aim to reduce the risk of recurrence and disease progression, as main TNBC tumors feature, as well as to develop more targeted and reduced toxic therapies for the six specific subtypes, previously described [130]. Theoretically, personalized treatments should improve stratification and timing of health care by utilizing biological information and biomarkers on the level of molecular disease pathways, genetics, proteomics, and metabolomics [131]. In this regard, it is imperative that we improve our understanding of biological processes such as epigenetic changes that occur by lncRNAs [132], considering lncRNA archetypes (shown in Fig. 1) for TNBC to reach that point, as a probable personalized epigenetic therapy. Efforts have been made in genomics to personalize the TNBC treatments that are currently oncological under use. This review has presented additional evidence that lncRNAs may work as diagnostic biomarkers and therapeutic targets in solid tumors, including $B C$ and TNBC. However, their relative expression levels in various subtypes of human BC [133], particularly the TNBC subtype, remain to be determined [134].

\section{Abbreviations}

AC: Adriamycin ${ }^{\circledast}$ and Cytoxan ${ }^{\circledast}$; ANKRD30A: Ankyrin repeat domain 30A; ARAIncRNA: Adriamycin resistance associated; ARF6: ADP-ribosylation factor 6; $\mathrm{BC}$ : Breast cancer; BCAR4: Breast cancer antiestrogen resistance 4; BLK: B lymphocyte kinase; BRCA1/2: Breast cancer 1/2; BRK: Breast tumor kinase; CCAT2: Colon cancer-associated transcript 2; CDK: Cyclin-dependent kinase; ceRNA: Competitive endogenous RNA; CYTOR: Cytoskeleton regulator RNA; DFS: Disease-free survival; DNMT: DNA methyltransferase; DTCs: Disseminated tumor cells; EGFR: Epidermal growth factor receptor; EMA: European

Medicines Agency; ER-a: Estrogen receptor alpha; ES+: Estrogen receptor positive; FDA: Food and Drug Administration; FdCyd: 5-Fluoro-2'-deoxcytidine; FGFR: Fibroblast growth factor receptor; GPNMB: Transmembrane glycoprotein NMB; GR: Glucocorticoid receptor; HB-EGF: Heparin-binding EGF-like growth factor; HDAC6: Histone deacetylase 6; HER2: Human epidermal growth factor receptor 2; HIF1a: Hypoxia-inducible factor 1-alpha; HOTAIR: HOX transcript antisense RNA; IGF-2: Insulin-like growth factor 2; IL1: Interleukin-1; iNOS: Inducible nitric oxide synthase; INPP4B: Inositol polyphosphate 4-phosphatase type II; IV: Intravenous; lincRNA-RoR: Long intergenic non-protein coding RNA regulator of reprogramming; LincRNARoR: Regulator of reprogramming; LINK-A: Long intergenic noncoding RNA for kinase activation; IncRNAs: Long noncoding ribonucleic acids; LRRK2: Leucine-rich repeat kinase 2; MALAT1: Metastasis-associated lung adenocarcinoma transcript 1; MAPK: Mitogen-activated protein kinase; miR- 
1: MicroRNA-1; miR-31: Tumor suppressor miRNA; miRNA: MicroRNA; MPS1: Serine/threonine kinase monopolar spindle 1; mTOR: Mammalian target of rapamycin; NAC: Neoadjuvant chemotherapy; ncRNA: Non-coding RNA; OA: Oral administration; PARP: Poly (ADP-ribose) polymerase; PCR: Pathological complete response; PD-1: Programmed cell death receptor; PDGF-R: Platelet-derived growth factor receptors; PDL1: Programmed cell death ligand-1; PI3K: Phosphatidylinositol 3-kinase; PR: Progesterone receptor; PRC2: Polycomb repressive complex 2; PTEN: Phosphatase and tensin homolog; RISC: RNA-induced silencing complex; RMST: Rhabdomyosarcoma 2-associated transcript; RNP: Ribonucleoprotein; SMDC: Small molecule drug conjugate; TFs: Transcription factors; THU: Tetrahydrouridine; TKRs: Tyrosine kinase receptors; TNBC: Triple-negative breast cancer; UCA1: Urothelial cancer associated 1 non-protein coding; UTR 3: Untranslated region 3'; VEGF: Vascular endothelial growth factor; VEGFR: Vascular endothelial growth factor receptor; WAVE3: WAS protein family member 3

\section{Authors' contributions}

All authors contributed to the conception of the article, writing, and revision of the final manuscript and agree on its submission to this journal.

\section{Ethics approval and consent to participate}

This review article did not involve the participation of any human or animal subjects.

\section{Competing interests}

The authors declare that they have no competing interests.

\section{Publisher's Note}

Springer Nature remains neutral with regard to jurisdictional claims in published maps and institutional affiliations.

\section{Author details}

${ }^{1}$ Thoracic Oncology Unit and Laboratory of Personalized Medicine, Instituto Nacional de Cancerología (INCan), San Fernando \#22, Section XVI, Tlalpan, 14080 Mexico City, Mexico. ${ }^{2}$ Biomedical Science Doctorate Program, National Autonomous University of Mexico, Mexico City, Mexico. ${ }^{3}$ Cancer Genomics Laboratory, INMEGEN, Mexico City, Mexico. ${ }^{4}$ Biochemistry Department, Instituto Nacional de Ciencias Médicas y Nutrición Salvador Zubirán, Mexico D.F, Mexico. ${ }^{5}$ Breast Oncology Department, National Cancer Institute of Mexico, Mexico City, Mexico. ${ }^{6} L u n g$ Diseases And Cancer Epigenomics Laboratory, Biomedicine Research Unit (UBIMED), Facultad de Estudios Superiores (FES) Iztacala, National University Autonomous of México (UNAM), Mexico City, Mexico. 'Research Unit, National Institute of Respiratory Diseases (INER) "Ismael Cosío Villegas", Mexico City, Mexico.

\section{Received: 8 December 2017 Accepted: 5 June 2018}

Published online: 27 June 2018

\section{References}

1. Mortality, G. B. D., and Causes of Death, C. Global, regional, and national life expectancy, all-cause mortality, and cause-specific mortality for 249 causes of death, 1980-2015: a systematic analysis for the Global Burden of Disease Study 2015. Lancet. 2016;388:1459-544.

2. Siegel RL, Miller KD, Jemal A. Cancer statistics, 2017. CA Cancer J Clin. 2017; 67:7-30.

3. Senkus E, Kyriakides S, Ohno S, Penault-Llorca F, Poortmans P, Rutgers E, Zackrisson S, Cardoso F, Committee EG. Primary breast cancer: ESMO Clinical Practice Guidelines for diagnosis, treatment and follow-up. Ann Oncol. 2015;26(Suppl 5):v8-30.

4. Perou CM, Sorlie T, Eisen MB, van de Rijn M, Jeffrey SS, Rees CA, Pollack JR, Ross DT, Johnsen H, Akslen LA, Fluge O, Pergamenschikov A, Williams C, Zhu SX, Lonning PE, Borresen-Dale AL, Brown PO, Botstein D. Molecular portraits of human breast tumours. Nature. 2000;406:747-52.

5. Polyak K. Heterogeneity in breast cancer. J Clin Invest. 2011;121:3786-8.

6. Marusyk A, Almendro V, Polyak K. Intra-tumour heterogeneity: a looking glass for cancer? Nat Rev Cancer. 2012;12:323-34.

7. Martelotto LG, Ng CK, Piscuoglio S, Weigelt B, Reis-Filho JS. Breast cance intra-tumor heterogeneity. Breast Cancer Res BCR. 2014;16:210.

8. Huarte M, Guttman M, Feldser D, Garber M, Koziol MJ, Kenzelmann-Broz D, Khalil AM, Zuk O, Amit I, Rabani M, Attardi LD, Regev A, Lander ES, Jacks T,
Rinn JL. A large intergenic noncoding RNA induced by p53 mediates global gene repression in the p53 response. Cell. 2010;142:409-19.

9. Koduru SV, Tiwari AK, Leberfinger A, Hazard SW, Kawasawa YI, Mahajan M, Ravnic DJ. A comprehensive NGS data analysis of differentially regulated miRNAs, piRNAs, IncRNAs and sn/snoRNAs in triple negative breast cancer. J Cancer. 2017:8:578-96.

10. Lin A, Li C, Xing Z, Hu Q, Liang K, Han L, Wang C, Hawke DH, Wang S, Zhang Y, Wei Y, Ma G, Park PK, Zhou J, Zhou Y, Hu Z, Zhou Y, Marks JR, Liang $H$, Hung $M-C$, Lin C, Yang L. The LINK-A IncRNA activates normoxic HIF1a signalling in triple-negative breast cancer. Nat Cell Biol. 2016;18:213.

11. Kong X, Liu W, Kong Y. Roles and expression profiles of long non-coding RNAs in triple-negative breast cancers. J Cell Mol Med. 2018;22:390-4.

12. Anders CK, Carey LA. Biology, metastatic patterns, and treatment of patients with triple-negative breast cancer. Clin Breast Cancer. 2009;9(Suppl 2):S73-81.

13. Anders C, Carey LA. Understanding and treating triple-negative breast cancer. Oncology. 2008;22:1233-9. discussion 1239-1240, 1243

14. Xie Y, Gou Q, Wang Q, Zhong X, Zheng $\mathrm{H}$. The role of BRCA status on prognosis in patients with triple-negative breast cancer. Oncotarget. 2017:8:87151-62.

15. Couch FJ, Hart SN, Sharma P, Toland AE, Wang X, Miron P, Olson JE, Godwin AK, Pankratz VS, Olswold C, Slettedahl S, Hallberg E, Guidugli L, Davila JI, Beckmann MW, Janni W, Rack B, Ekici AB, Slamon DJ, Konstantopoulou I, Fostira F, Vratimos A, Fountzilas G, Pelttari LM, Tapper WJ, Durcan L, Cross SS, Pilarski R, Shapiro CL, Klemp J, Yao S, Garber J, Cox A, Brauch H, Ambrosone C, Nevanlinna H, Yannoukakos D, Slager SL, Vachon CM, Eccles DM, Fasching PA. Inherited mutations in 17 breast cancer susceptibility genes among a large triple-negative breast cancer cohort unselected for family history of breast cancer. J Clin Oncol. 2015;33:304-11.

16. Greenup R, Buchanan A, Lorizio W, Rhoads K, Chan S, Leedom T, King R, McLennan J, Crawford B, Kelly Marcom P, Shelley Hwang E. Prevalence of BRCA mutations among women with triple-negative breast cancer (TNBC) in a genetic counseling cohort. Ann Surg Oncol. 2013;20:3254-8.

17. Curtis C, Shah SP, Chin SF, Turashvili G, Rueda OM, Dunning M, Speed D, Lynch AG, Samarajiwa S, Yuan Y, Graf S, Ha G, Haffari G, Bashashati A, Russell R, McKinney S, Group, M, Langerod A, Green A, Provenzano E, Wishart G, Pinder S, Watson P, Markowetz F, Murphy L, Ellis I, Purushotham A, Borresen-Dale AL, Brenton JD, Tavare S, Caldas C, Aparicio S. The genomic and transcriptomic architecture of 2,000 breast tumours reveals novel subgroups. Nature. 2012;486:346-52.

18. Shah SP, Roth A, Goya R, Oloumi A, Ha G, Zhao Y, Turashvili G, Ding J, Tse K, Haffari G, Bashashati A, Prentice LM, Khattra J, Burleigh A, Yap D, Bernard V, McPherson A, Shumansky K, Crisan A, Giuliany R, Heravi-Moussavi A, Rosner J, Lai D, Birol I, Varhol R, Tam A, Dhalla N, Zeng T, Ma K, Chan SK, Griffith M, Moradian A, Cheng SW, Morin GB, Watson P, Gelmon K, Chia S, Chin SF, Curtis C, Rueda OM, Pharoah PD, Damaraju S, Mackey J, Hoon K, Harkins T, Tadigotla V, Sigaroudinia M, Gascard P, TIsty T, Costello JF, Meyer IM, Eaves CJ, Wasserman WW, Jones S, Huntsman D, Hirst M, Caldas C, Marra MA, Aparicio S. The clonal and mutational evolution spectrum of primary triplenegative breast cancers. Nature. 2012;486:395-9.

19. Pal SK, Childs BH, Pegram M. Triple negative breast cancer: unmet medical needs. Breast Cancer Res Treat. 2011;125:627-36.

20. Cancer Genome Atlas N. Comprehensive molecular portraits of human breast tumours. Nature. 2012:490:61-70.

21. Rakha EA, Ellis IO. Triple-negative/basal-like breast cancer: review. Pathology. 2009:41:40-7.

22. Symmans WF, Peintinger F, Hatzis C, Rajan R, Kuerer H, Valero V, Assad L, Poniecka A, Hennessy B, Green M, Buzdar AU, Singletary SE, Hortobagyi GN, Pusztai L. Measurement of residual breast cancer burden to predict survival after neoadjuvant chemotherapy. J Clin Oncol. 2007;25:4414-22.

23. Liedtke C, Mazouni C, Hess KR, Andre F, Tordai A, Mejia JA, Symmans WF, Gonzalez-Angulo AM, Hennessy B, Green M, Cristofanilli M, Hortobagyi GN Pusztai L. Response to neoadjuvant therapy and long-term survival in patients with triple-negative breast cancer. J Clin Oncol. 2008;26:1275-81.

24. Foulkes WD, Smith IE, Reis-Filho JS. Triple-negative breast cancer. N Engl J Med. 2010;363:1938-48.

25. Lara-Medina F, Perez-Sanchez V, Saavedra-Perez D, Blake-Cerda M, Arce C, Motola-Kuba D, Villarreal-Garza C, Gonzalez-Angulo AM, Bargallo E, Aguilar $J$, Mohar A, Arrieta O. Triple-negative breast cancer in Hispanic patients: high prevalence, poor prognosis, and association with menopausal status, body mass index, and parity. Cancer. 2011:117:3658-69.

26. Dent R, Trudeau M, Pritchard KI, Hanna WM, Kahn HK, Sawka CA, Lickley LA, Rawlinson E, Sun P, Narod SA. Triple-negative breast cancer: clinical features and patterns of recurrence. Clin Cancer Res. 2007;13:4429-34. 
27. $\mathrm{Ng}$ CK, Schultheis AM, Bidard FC, Weigelt B, Reis-Filho JS. Breast cancer genomics from microarrays to massively parallel sequencing: paradigms and new insights. J Natl Cancer Inst. 2015;107 https://doi.org/10.1093/jnci/djv015.

28. Kandoth C, McLellan MD, Vandin F, Ye K, Niu B, Lu C, Xie M, Zhang Q, McMichael JF, Wyczalkowski MA, Leiserson MDM, Miller CA, Welch JS, Walter MJ, Wendl MC, Ley TJ, Wilson RK, Raphael BJ, Ding L. Mutational landscape and significance across 12 major cancer types. Nature. 2013;502:333-9.

29. Nik-Zainal S, Davies H, Staaf J, Ramakrishna M, Glodzik D, Zou X, Martincorena I, Alexandrov LB, Martin S, Wedge DC, Van Loo P, Ju YS, Smid M, Brinkman AB, Morganella S, Aure MR, Lingjaerde OC, Langerod A, Ringner M, Ahn SM, Boyault S, Brock JE, Broeks A, Butler A, Desmedt C, Dirix L, Dronov S, Fatima A, Foekens JA, Gerstung M, Hooijer GK, Jang SJ, Jones DR, Kim HY, King TA, Krishnamurthy S, Lee HJ, Lee JY, Li Y, McLaren S, Menzies A, Mustonen V, O'Meara S, Pauporte I, Pivot X, Purdie CA, Raine K, Ramakrishnan K, Rodriguez-Gonzalez FG, Romieu G, Sieuwerts AM, Simpson PT, Shepherd R, Stebbings L, Stefansson OA, Teague J, Tommasi S, Treilleux I, Van den Eynden GG, Vermeulen P, Vincent-Salomon A, Yates L, Caldas C, van't Veer L, Tutt A, Knappskog S, Tan BK, Jonkers J, Borg A, Ueno NT, Sotiriou C, Viari A, Futreal PA, Campbell PJ, Span PN, Van Laere S, Lakhani SR, Eyfjord JE, Thompson AM, Birney E, Stunnenberg HG, van de Vijver MJ, Martens JW, Borresen-Dale AL, Richardson AL, Kong G, Thomas G, Stratton MR. Landscape of somatic mutations in 560 breast cancer whole-genome sequences. Nature. 2016;534:47-54.

30. Gao Y, Jones A, Fasching PA, Ruebner M, Beckmann MW, Widschwendter M, Teschendorff AE. The integrative epigenomic-transcriptomic landscape of ER positive breast cancer. Clin Epigenetics. 2015;7:126.

31. Hicks J, Krasnitz A, Lakshmi B, Navin NE, Riggs M, Leibu E, Esposito D, Alexander J, Troge J, Grubor V, Yoon S, Wigler M, Ye K, Borresen-Dale AL, Naume B, Schlicting E, Norton L, Hagerstrom T, Skoog L, Auer G, Maner S, Lundin P, Zetterberg A. Novel patterns of genome rearrangement and their association with survival in breast cancer. Genome Res. 2006;16:1465-79.

32. Stefansson OA, Moran S, Gomez A, Sayols S, Arribas-Jorba C, Sandoval J, Hilmarsdottir H, Olafsdottir E, Tryggvadottir L, Jonasson JG, Eyfjord J, Esteller M. A DNA methylation-based definition of biologically distinct breast cancer subtypes. Mol Oncol. 2015;9:555-68.

33. Mathe A, Wong-Brown M, Locke WJ, Stirzaker C, Braye SG, Forbes JF, Clark SJ, Avery-Kiejda KA, Scott RJ. DNA methylation profile of triple negative breast cancer-specific genes comparing lymph node positive patients to lymph node negative patients. Sci Rep. 2016;6:33435.

34. Fatica A, Bozzoni I. Long non-coding RNAs: new players in cell differentiation and development. Nat Rev Genet. 2014;15:7-21.

35. Hauptman N, Glavac D. Long non-coding RNA in cancer. Int J Mol Sci. 2013; 14:4655-69.

36. Esteller M. Non-coding RNAs in human disease. Nat Rev Genet. 2011;12:861-74.

37. Liu B, Sun L, Liu Q, Gong C, Yao Y, Lv X, Lin L, Yao H, Su F, Li D, Zeng M, Song E. A cytoplasmic NF-kappaB interacting long noncoding RNA blocks IkappaB phosphorylation and suppresses breast cancer metastasis. Cancer Cell. 2015;27:370-81.

38. Liu YR, Jiang YZ, Xu XE, Yu KD, Jin X, Hu X, Zuo WJ, Hao S, Wu J, Liu GY, D GH, Li DQ, He XH, Hu WG, Shao ZM. Comprehensive transcriptome analysis identifies novel molecular subtypes and subtype-specific RNAs of triplenegative breast cancer. Breast Cancer Res BCR. 2016;18:33.

39. Cheetham SW, Gruhl F, Mattick JS, Dinger ME. Long noncoding RNAs and the genetics of cancer. Br J Cancer. 2013;108:2419-25.

40. Hon CC, Ramilowski JA, Harshbarger J, Bertin N, Rackham OJ, Gough J, Denisenko E, Schmeier S, Poulsen TM, Severin J, Lizio M, Kawaji H, Kasukawa T, Itoh M, Burroughs AM, Noma S, Djebali S, Alam T, Medvedeva YA, Testa AC, Lipovich L, Yip CW, Abugessaisa I, Mendez M, Hasegawa A, Tang D, Lassmann T, Heutink P, Babina M, Wells CA, Kojima S, Nakamura Y, Suzuki H, Daub CO, de Hoon MJ, Arner E, Hayashizaki Y, Carninci P, Forrest AR. An atlas of human long non-coding RNAs with accurate 5' ends. Nature. 2017;543:199-204.

41. Fedele P, Orlando L, Cinieri S. Targeting triple negative breast cancer with histone deacetylase inhibitors. Expert Opin Investig Drugs. 2017;26:1199-206.

42. Tsai M-C, Manor O, Wan Y, Mosammaparast N, Wang JK, Lan F, Shi Y, Segal E, Chang HY. Long noncoding RNA as modular scaffold of histone modification complexes. Science. 2010;329:689.

43. Kohler BA, Sherman RL, Howlader N, Jemal A, Ryerson AB, Henry KA, Boscoe FP, Cronin KA, Lake A, Noone AM, Henley SJ, Eheman CR, Anderson RN, Penberthy L. Annual report to the nation on the status of cancer, 19752011, featuring incidence of breast cancer subtypes by race/ethnicity, poverty, and state. J Natl Cancer Inst. 2015;107:djv048.
44. Coates, A. S., Winer, E. P., Goldhirsch, A., Gelber, R. D., Gnant, M., PiccartGebhart, M., Thurlimann, B., Senn, H. J., and Panel, M. Tailoring therapies-improving the management of early breast cancer: St Gallen International Expert Consensus on the Primary Therapy of Early Breast Cancer 2015. Ann Oncol. 2015;26:1533-46.

45. Cortazar P, Zhang L, Untch M, Mehta K, Costantino JP, Wolmark N, Bonnefoi H, Cameron D, Gianni L, Valagussa P, Swain SM, Prowell T, Loibl S, Wickerham DL, Bogaerts J, Baselga J, Perou C, Blumenthal G, Blohmer J, Mamounas EP, Bergh J, Semiglazov V, Justice R, Eidtmann H, Paik S, Piccart M, Sridhara R, Fasching PA, Slaets L, Tang S, Gerber B, Geyer CE Jr, Pazdur R, Ditsch N, Rastogi P, Eiermann W, von Minckwitz G. Pathological complete response and long-term clinical benefit in breast cancer: the CTNeoBC pooled analysis. Lancet. 2014;384:164-72.

46. Kaufmann, M., Hortobagyi, G. N., Goldhirsch, A., Scholl, S., Makris, A., Valagussa, P., Blohmer, J. U., Eiermann, W., Jackesz, R., Jonat, W., Lebeau, A., Loibl, S., Miller, W., Seeber, S., Semiglazov, V., Smith, R., Souchon, R., Stearns, V., Untch, M., and von Minckwitz, G. Recommendations from an international expert panel on the use of neoadjuvant (primary) systemic treatment of operable breast cancer: an update. J Clin Oncol. 2006; 24: 1940-1949.

47. Golshan M, Cirrincione $C$, Sikov WM, Berry DA, Jasinski S, Weisberg TF, Somlo G, Hudis C, Winer E, Ollila DW, Alliance for Clinical Trials in, O. Impact of neoadjuvant chemotherapy in stage II-III triple negative breast cancer on eligibility for breastconserving surgery and breast conservation rates: surgical results from CALGB 40603 (Alliance). Ann Surg. 2015;262:434-9. discussion 438-439

48. von Minckwitz G, Untch M, Blohmer JU, Costa SD, Eidtmann H, Fasching PA, Gerber B, Eiermann W, Hilfrich J, Huober J, Jackisch C, Kaufmann M, Konecny GE, Denkert C, Nekljudova V, Mehta K, Loibl S. Definition and impact of pathologic complete response on prognosis after neoadjuvant chemotherapy in various intrinsic breast cancer subtypes. J Clin Oncol. 2012; 30:1796-804.

49. Tan DS, Marchio C, Jones RL, Savage K, Smith IE, Dowsett M, Reis-Filho JS. Triple negative breast cancer: molecular profiling and prognostic impact in adjuvant anthracycline-treated patients. Breast Cancer Res Treat. 2008;111:27-44.

50. Haffty BG, Yang Q, Reiss M, Kearney T, Higgins SA, Weidhaas J, Harris L, Hait $W$, Toppmeyer D. Locoregional relapse and distant metastasis in conservatively managed triple negative early-stage breast cancer. J Clin Oncol. 2006;24:5652-7.

51. Silver DP, Richardson AL, Eklund AC, Wang ZC, Szallasi Z, Li Q, Juul N, Leong CO, Calogrias D, Buraimoh A, Fatima A, Gelman RS, Ryan PD, Tung NM, De Nicolo A, Ganesan S, Miron A, Colin C, Sgroi DC, Ellisen LW, Winer EP, Garber JE. Efficacy of neoadjuvant Cisplatin in triple-negative breast cancer. J Clin Oncol. 2010;28:1145-53.

52. Byrski T, Huzarski T, Dent R, Marczyk E, Jasiowka M, Gronwald J, Jakubowicz J, Cybulski C, Wisniowski R, Godlewski D, Lubinski J, Narod SA. Pathologic complete response to neoadjuvant cisplatin in BRCA1-positive breast cancer patients. Breast Cancer Res Treat. 2014;147:401-5.

53. Andrew Tutt PE, Kilburn L, Gilett C, Pinder S, Abraham J, Barrett S, BarrettLee P, Chan S, Cheang M, Dowsett M, Fox L, Gazinska P, Grigoriadis A, Gutin A, Harper-Wynne C, Hatton M, Kernaghan S, Lanchbury J, Morden J, Owen J, Parikh J, Parker P, Rahman N, Roylance R, Shaw A, Smith I, Thompson R, Timms K, Tovey H, Wardley A, Wilson G, Harries M, Bliss J. The TNT trial: a randomized phase III trial of carboplatin (C) compared with docetaxel (D) for patients with metastatic or recurrent locally advanced triple negative or BRCA1/2 breast cancer (CRUK/07/012). Cancer Res. 2015;75:S3-01. AACR

54. Lehmann BD, Pietenpol JA, Tan AR. Triple-negative breast cancer: molecular subtypes and new targets for therapy. Am Soc Clin Oncol Educ Book. 2015: e31-9. https://doi.org/10.14694/EdBook_AM.2015.35.e31.

55. Robson M, Im SA, Senkus E, Xu B, Domchek SM, Masuda N, Delaloge S, Li W, Tung N, Armstrong A, Wu W, Goessl C, Runswick S, Conte P. Olaparib for metastatic breast cancer in patients with a germline BRCA mutation. N Engl J Med. 2017:377:523-33.

56. Stemke-Hale K, Gonzalez-Angulo AM, Lluch A, Neve RM, Kuo WL, Davies M, Carey M, Hu Z, Guan Y, Sahin A, Symmans WF, Pusztai L, Nolden LK, Horlings H, Berns K, Hung MC, van de Vijver MJ, Valero V, Gray JW, Bernards R, Mills GB, Hennessy BT. An integrative genomic and proteomic analysis of PIK3CA, PTEN, and AKT mutations in breast cancer. Cancer Res. 2008;68:6084-91.

57. Marty B, Maire V, Gravier E, Rigaill G, Vincent-Salomon A, Kappler M, Lebigot I, Djelti F, Tourdes A, Gestraud P, Hupe P, Barillot E, Cruzalegui F, Tucker GC, Stern MH, Thiery JP, Hickman JA, Dubois T. Frequent PTEN genomic alterations and activated phosphatidylinositol 3-kinase pathway in basal-like breast cancer cells. Breast Cancer Res BCR. 2008;10:R101. 
58. Gewinner C, Wang ZC, Richardson A, Teruya-Feldstein J, Etemadmoghadam D, Bowtell D, Barretina J, Lin WM, Rameh L, Salmena L, Pandolfi PP, Cantley LC. Evidence that inositol polyphosphate 4-phosphatase type II is a tumor suppressor that inhibits PI3K signaling. Cancer Cell. 2009;16:115-25.

59. Banerji S, Cibulskis K, Rangel-Escareno C, Brown KK, Carter SL, Frederick AM, Lawrence MS, Sivachenko AY, Sougnez C, Zou L, Cortes ML, FernandezLopez JC, Peng S, Ardlie KG, Auclair D, Bautista-Pina V, Duke F, Francis J, Jung J, Maffuz-Aziz A, Onofrio RC, Parkin M, Pho NH, Quintanar-Jurado V, Ramos AH, Rebollar-Vega R, Rodriguez-Cuevas S, Romero-Cordoba SL, Schumacher SE, Stransky N, Thompson KM, Uribe-Figueroa L, Baselga J, Beroukhim R, Polyak K, Sgroi DC, Richardson AL, Jimenez-Sanchez G, Lander ES, Gabriel SB, Garraway LA, Golub TR, Melendez-Zajgla J, Toker A, Getz G, Hidalgo-Miranda A, Meyerson M. Sequence analysis of mutations and translocations across breast cancer subtypes. Nature. 2012;486:405-9.

60. Isakoff SJ, J. C. B, Cervantes A, Soria J-C, Molife LR, Sanabria-Bohorquez SM, Punnoose EA, Jia S, Patel P, Saura C. Phase Ib dose-escalation study of an Akt inhibitor ipatasertib (Ipat) in combination with docetaxel (Doc) or paclitaxel (Pac) in patients (pts) with metastatic breast cancer (MBC). In: Thirty-seventh annual CTRC-AACR San Antonio breast cancer symposium, vol. 75. San Antonio, Texas; 2015. p. PC-12-02.

61. Baselga J, Gomez P, Greil R, Braga S, Climent MA, Wardley AM, Kaufman B, Stemmer SM, Pego A, Chan A, Goeminne JC, Graas MP, Kennedy MJ, Ciruelos Gil EM, Schneeweiss A, Zubel A, Groos J, Melezinkova H, Awada A. Randomized phase II study of the anti-epidermal growth factor receptor monoclonal antibody cetuximab with cisplatin versus cisplatin alone in patients with metastatic triplenegative breast cancer. J Clin Oncol. 2013;31:2586-92.

62. Carey LA, Rugo HS, Marcom PK, Mayer EL, Esteva FJ, Ma CX, Liu MC, Storniolo AM, Rimawi MF, Forero-Torres A, Wolff AC, Hobday TJ, Ivanova A, Chiu WK, Ferraro M, Burrows E, Bernard PS, Hoadley KA, Perou CM, Winer EP. TBCRC 001: randomized phase II study of cetuximab in combination with carboplatin in stage IV triple-negative breast cancer. J Clin Oncol. 2012; 30:2615-23.

63. Brufsky A, Valero V, Tiangco B, Dakhil S, Brize A, Rugo HS, Rivera R, Duenne A, Bousfoul N, Yardley DA. Second-line bevacizumab-containing therapy in patients with triple-negative breast cancer: subgroup analysis of the RIBBON-2 trial. Breast Cancer Res Treat. 2012;133:1067-75.

64. Miles DW, Dieras V, Cortes J, Duenne AA, Yi J, O'Shaughnessy J. First-line bevacizumab in combination with chemotherapy for HER2-negative metastatic breast cancer: pooled and subgroup analyses of data from 2447 patients. Ann Oncol. 2013;24:2773-80.

65. Cameron D, Brown J, Dent R, Jackisch C, Mackey J, Pivot X, Steger GG, Suter TM, Toi M, Parmar M, Laeufle R, Im YH, Romieu G, Harvey V, Lipatov O, Pienkowski T, Cottu P, Chan A, Im SA, Hall PS, Bubuteishvili-Pacaud L, Henschel V, Deurloo RJ, Pallaud C, Bell R. Adjuvant bevacizumab-containing therapy in triple-negative breast cancer (BEATRICE): primary results of a randomised, phase 3 trial. Lancet Oncol. 2013;14:933-42.

66. Ciardiello F, Tortora G. EGFR antagonists in cancer treatment. N Engl J Med. 2008;358:1160-74

67. Corkery B, Crown J, Clynes M, O'Donovan N. Epidermal growth factor receptor as a potential therapeutic target in triple-negative breast cancer. Ann Oncol. 2009;20:862-7.

68. Finn RS, Press MF, Dering J, Arbushites M, Koehler M, Oliva C, Williams LS, Di Leo A. Estrogen receptor, progesterone receptor, human epidermal growth factor receptor 2 (HER2), and epidermal growth factor receptor expression and benefit from lapatinib in a randomized trial of paclitaxel with lapatinib or placebo as first-line treatment in HER2-negative or unknown metastatic breast cancer. J Clin Oncol. 2009;27:3908-15.

69. Lo YH, Ho PC, Zhao H, Wang SC. Inhibition of c-ABL sensitizes breast cancer cells to the dual ErbB receptor tyrosine kinase inhibitor lapatinib (GW572016). Anticancer Res. 2011;31:789-95.

70. Turner N, Lambros MB, Horlings HM, Pearson A, Sharpe R, Natrajan R, Geyer FC, van Kouwenhove M, Kreike B, Mackay A, Ashworth A, van de Vijver MJ, Reis-Filho JS. Integrative molecular profiling of triple negative breast cancers identifies amplicon drivers and potential therapeutic targets. Oncogene. 2010;29:2013-23

71. Cerami E, Gao J, Dogrusoz U, Gross BE, Sumer SO, Aksoy BA, Jacobsen A Byrne CJ, Heuer ML, Larsson E, Antipin Y, Reva B, Goldberg AP, Sander C, Schultz N. The cBio cancer genomics portal: an open platform for exploring multidimensional cancer genomics data. Cancer Discov. 2012;2:401-4.

72. Niemeier LA, Dabbs DJ, Beriwal S, Striebel JM, Bhargava R. Androgen receptor in breast cancer: expression in estrogen receptor-positive tumors and in estrogen receptor-negative tumors with apocrine differentiation. Modern Pathol. 2010;23:205-12.

73. Janssen Research \& Development, L. A study to evaluate the safety, pharmacokinetics, and pharmacodynamics of JNJ-42756493 in patients with advanced or refractory solid tumors or lymphoma. 2016.

74. Gucalp A, Tolaney S, Isakoff SJ, Ingle JN, Liu MC, Carey LA, Blackwell K, Rugo H, Nabell L, Forero A, Stearns V, Doane AS, Danso M, Moynahan ME, Momen LF, Gonzalez JM, Akhtar A, Giri DD, Patil S, Feigin KN, Hudis CA, Traina TA, Translational Breast Cancer Research C. Phase II trial of bicalutamide in patients with androgen receptor-positive, estrogen receptor-negative metastatic breast cancer. Clin Cancer Res. 2013;19:5505-12

75. Traina, J. C. C. P. S. A. A. H. U. I. C. T. M. E. B. J. L. S. D. A. Y. C. H. T. A. Stage 1 results from MDV3100-11: a 2-stage study of enzalutamide (ENZA), an androgen receptor (AR) inhibitor, in advanced $A R+$ triple-negative breast cancer (TNBC). Ann Oncol. 2015;26:iii6.

76. Yamaoka M, Hara T, Hitaka T, Kaku T, Takeuchi T, Takahashi J, Asahi S, Miki H, Tasaka A, Kusaka M. Orteronel (TAK-700), a novel non-steroidal 17,20-lyase inhibitor: effects on steroid synthesis in human and monkey adrenal cells and serum steroid levels in cynomolgus monkeys. J Steroid Biochem Mol Biol. 2012;129:115-28.

77. Huarte M. The emerging role of IncRNAs in cancer. Nat Med. 2015;21:1253-61.

78. Evans JR, Feng FY, Chinnaiyan AM. The bright side of dark matter: IncRNAs in cancer. J Clin Invest. 2016;126:2775-82.

79. Yang F, Liu YH, Dong SY, Yao ZH, Lv L, Ma RM, Dai XX, Wang J, Zhang XH, Wang OC. Co-expression networks revealed potential core IncRNAs in the triple-negative breast cancer. Gene. 2016;591:471-7.

80. Djebali S, Davis CA, Merkel A, Dobin A, Lassmann T, Mortazavi A, Tanzer A, Lagarde J, Lin W, Schlesinger F, Xue C, Marinov GK, Khatun J, Williams BA, Zaleski C, Rozowsky J, Roder M, Kokocinski F, Abdelhamid RF, Alioto T, Antoshechkin I, Baer MT, Bar NS, Batut P, Bell K, Bell I, Chakrabortty S, Chen $X$, Chrast J, Curado J, Derrien T, Drenkow J, Dumais E, Dumais J, Duttagupta R, Falconnet E, Fastuca M, Fejes-Toth K, Ferreira P, Foissac S, Fullwood MJ, Gao H, Gonzalez D, Gordon A, Gunawardena H, Howald C, Jha S, Johnson R, Kapranov P, King B, Kingswood C, Luo OJ, Park E, Persaud K, Preall JB, Ribeca P, Risk B, Robyr D, Sammeth M, Schaffer L, See LH, Shahab A, Skancke J, Suzuki AM, Takahashi H, Tilgner H, Trout D, Walters N, Wang H, Wrobel J, Yu Y, Ruan X, Hayashizaki Y, Harrow J, Gerstein M, Hubbard T, Reymond A, Antonarakis SE, Hannon G, Giddings MC, Ruan Y, Wold B, Carninci P, Guigo R, Gingeras TR. Landscape of transcription in human cells. Nature. 2012;489:101-8.

81. Sana J, Faltejskova P, Svoboda M, Slaby O. Novel classes of non-coding RNAs and cancer. J Transl Med. 2012;10:103.

82. Wilusz JE, Sunwoo H, Spector DL. Long noncoding RNAs: functional surprises from the RNA world. Genes Dev. 2009;23:1494-504.

83. Ponting CP, Oliver PL, Reik W. Evolution and functions of long noncoding RNAs. Cell. 2009;136:629-41.

84. Mercer TR, Mattick JS. Structure and function of long noncoding RNAs in epigenetic regulation. Nat Struct Mol Biol. 2013;20:300-7.

85. Derrien T, Johnson R, Bussotti G, Tanzer A, Djebali S, Tilgner H, Guernec G, Martin D, Merkel A, Knowles DG, Lagarde J, Veeravalli L, Ruan X, Ruan Y, Lassmann T, Carninci P, Brown JB, Lipovich L, Gonzalez JM, Thomas M, Davis CA, Shiekhattar R, Gingeras TR, Hubbard TJ, Notredame C, Harrow J, Guigo R. The GENCODE 77 catalog of human long noncoding RNAs: analysis of their gene structure, evolution, and expression. Genome Res. 2012;22:1775-89.

86. Morlando M, Ballarino M, Fatica A, Bozzoni I. The role of long noncoding RNAs in the epigenetic control of gene expression. ChemMedChem. 2014;9:505-10.

87. Vance KW, Ponting CP. Transcriptional regulatory functions of nuclear long noncoding RNAs. Trends Genet. 2014;30:348-55.

88. Gutschner T, Diederichs S. The hallmarks of cancer: a long non-coding RNA point of view. RNA Biol. 2012;9:703-19.

89. Zhao W, Luo J, Jiao S. Comprehensive characterization of cancer subtype associated long non-coding RNAs and their clinical implications. Sci Rep. 2014:4:6591.

90. Prensner JR, lyer MK, Sahu A, Asangani IA, Cao Q, Patel L, Vergara IA, Davicioni E, Erho N, Ghadessi M, Jenkins RB, Triche TJ, Malik R, Bedenis R, McGregor N, Ma T, Chen W, Han S, Jing X, Cao X, Wang X, Chandler B, Yan W, Siddiqui J, Kunju LP, Dhanasekaran SM, Pienta KJ, Feng FY, Chinnaiyan AM. The long noncoding RNA SChLAP1 promotes aggressive prostate cancer and antagonizes the SWI/SNF complex. Nat Genet. 2013;45:1392-8.

91. Yuan JH, Yang F, Wang F, Ma JZ, Guo YJ, Tao QF, Liu F, Pan W, Wang TT, Zhou CC, Wang SB, Wang YZ, Yang Y, Yang N, Zhou WP, Yang GS, Sun SH. 
A long noncoding RNA activated by TGF-beta promotes the invasionmetastasis cascade in hepatocellular carcinoma. Cancer Cell. 2014;25:666-81.

92. Prensner JR, Chinnaiyan AM. The emergence of IncRNAs in cancer biology. Cancer Discov. 2011;1:391-407.

93. Vikram R, Ramachandran R, Abdul KS. Functional significance of long noncoding RNAs in breast cancer. Breast Cancer. 2014;21:515-21.

94. Guo L, Zhao Y, Yang S, Zhang H, Wu Q, Chen F. An integrated evolutionary analysis of miRNA-IncRNA in mammals. Mol Biol Rep. 2014:41:201-7.

95. Yang X, Gao L, Guo X, Shi X, Wu H, Song F, Wang B. A network based method for analysis of IncRNA-disease associations and prediction of IncRNAs implicated in diseases. PLoS One. 2014;9:e87797.

96. Berteaux N, Lottin S, Monte D, Pinte S, Quatannens B, Coll J, Hondermarck H, Curgy JJ, Dugimont T, Adriaenssens E. H19 mRNA-like noncoding RNA promotes breast cancer cell proliferation through positive control by E2F1. J Biol Chem. 2005;280:29625-36.

97. Gupta RA, Shah N, Wang KC, Kim J, Horlings HM, Wong DJ, Tsai MC, Hung T, Argani P, Rinn JL, Wang Y, Brzoska P, Kong B, Li R, West RB, van de Vijver MJ, Sukumar S, Chang HY. Long non-coding RNA HOTAIR reprograms chromatin state to promote cancer metastasis. Nature. 2010;464:1071-6.

98. Huang J, Zhou N, Watabe K, Lu Z, Wu F, Xu M, Mo YY. Long non-coding RNA UCA1 promotes breast tumor growth by suppression of p27 (Kip1). Cell Death Dis. 2014;5:e1008.

99. Mourtada-Maarabouni M, Pickard MR, Hedge VL, Farzaneh F, Williams GT. GAS5, a non-protein-coding RNA, controls apoptosis and is downregulated in breast cancer. Oncogene. 2009;28:195-208.

100. Huarte M, Rinn JL. Large non-coding RNAs: missing links in cancer? Hum Mol Genet. 2010;19:R152-61.

101. Van Grembergen O, Bizet M, de Bony EJ, Calonne E, Putmans P, Brohee S, Olsen C, Guo M, Bontempi G, Sotiriou C, Defrance M, Fuks F. Portraying breast cancers with long noncoding RNAs. Sci Adv. 2016;2:e1600220.

102. Jiang M, Huang $O$, Xie Z, Wu S, Zhang $X$, Shen A, Liu H, Chen X, Wu J, Lou Y, Mao Y, Sun K, Hu S, Geng M, Shen K. A novel long non-coding RNA-ARA: adriamycin resistance-associated. Biochem Pharmacol. 2014;87:254-83.

103. Godinho M, Meijer D, Setyono-Han B, Dorssers LC, van Agthoven T. Characterization of BCAR4, a novel oncogene causing endocrine resistance in human breast cancer cells. J Cell Physiol. 2011;226:1741-9.

104. Godinho MF, Wulfkuhle JD, Look MP, Sieuwerts AM, Sleijfer S, Foekens JA, Petricoin EF 3rd, Dorssers LC, van Agthoven T. BCAR4 induces antioestrogen resistance but sensitises breast cancer to lapatinib. Br J Cancer. 2012;107: 947-55.

105. Redis RS, Sieuwerts AM, Look MP, Tudoran O, Ivan C, Spizzo R, Zhang X, de Weerd V, Shimizu M, Ling H, Buiga R, Pop V, Irimie A, Fodde R, Bedrosian I, Martens JW, Foekens JA, Berindan-Neagoe I, Calin GA. CCAT2, a novel long non-coding RNA in breast cancer: expression study and clinical correlations. Oncotarget. 2013:4:1748-62.

106. Liu M, Xing LQ, Liu YJ. A three-long noncoding RNA signature as a diagnostic biomarker for differentiating between triple-negative and nontriple-negative breast cancers. Medicine. 2017;96:e6222.

107. Wang F, Dohogne Z, Yang J, Liu Y, Soibam B. Predictors of breast cancer cell types and their prognostic power in breast cancer patients. BMC Genomics. 2018;19:137.

108. Shen X, Xie B, Ma Z, Yu W, Wang W, Xu D, Yan X, Chen B, Yu L, Li J, Chen X, Ding $K$, Cao F. Identification of novel long non-coding RNAs in triplenegative breast cancer. Oncotarget. 2015;6:21730-9.

109. Chung W, Eum HH, Lee HO, Lee KM, Lee HB, Kim KT, Ryu HS, Kim S, Lee JE, Park YH, Kan Z, Han W, Park WY. Single-cell RNA-seq enables comprehensive tumour and immune cell profiling in primary breast cancer. Nat Commun. 2017:8:15081.

110. Chen C, Li Z, Yang Y, Xiang T, Song W, Liu S. Microarray expression profiling of dysregulated long non-coding RNAs in triple-negative breast cancer. Cancer Biol Ther. 2015;16:856-65.

111. Varga Z, Theurillat JP, Filonenko V, Sasse B, Odermatt B, Jungbluth AA, Chen YT, Old LJ, Knuth A, Jager D, Moch H. Preferential nuclear and cytoplasmic NY-BR-1 protein expression in primary breast cancer and lymph node metastases. Clin Cancer Res. 2006;12:2745-51.

112. Klein CA. Framework models of tumor dormancy from patient-derived observations. Curr Opin Genet Dev. 2011;21:42-9.

113. Lacroix M. Significance, detection and markers of disseminated breast cancer cells. Endocr Relat Cancer. 2006;13:1033-67.

114. Balafoutas D, zur Hausen A, Mayer S, Hirschfeld M, Jaeger M, Denschlag D, Gitsch G, Jungbluth A, Stickeler E. Cancer testis antigens and NY-BR-1 expression in primary breast cancer: prognostic and therapeutic implications. BMC Cancer. 2013;13:271.

115. Loewer S, Cabili MN, Guttman M, Loh YH, Thomas K, Park IH, Garber M, Curran M, Onder T, Agarwal S, Manos PD, Datta S, Lander ES, Schlaeger TM, Daley GQ, Rinn JL. Large intergenic non-coding RNA-RoR modulates reprogramming of human induced pluripotent stem cells. Nat Genet. 2010; 42:1113-7.

116. Wang Y, Xu Z, Jiang J, Xu C, Kang J, Xiao L, Wu M, Xiong J, Guo X, Liu H. Endogenous miRNA sponge lincRNA-RoR regulates Oct4, Nanog, and Sox2 in human embryonic stem cell self-renewal. Dev Cell. 2013;25:69-80.

117. Hashimoto S, Onodera Y, Hashimoto A, Tanaka M, Hamaguchi M, Yamada A, Sabe H. Requirement for Arf6 in breast cancer invasive activities. Proc Natl Acad Sci U S A. 2004;101:6647-52.

118. Eades G, Wolfson B, Zhang Y, Li Q, Yao Y, Zhou Q. lincRNA-RoR and miR-145 regulate invasion in triple-negative breast cancer via targeting ARF6. Mol Cancer Res. 2015;13:330-8.

119. Wang YL, Overstreet AM, Chen MS, Wang J, Zhao HJ, Ho PC, Smith M, Wang SC. Combined inhibition of EGFR and C-ABL suppresses the growth of triple-negative breast cancer growth through inhibition of HOTAIR. Oncotarget. 2015;6:11150-61.

120. Jin C, Yan B, Lu Q, Lin Y, Ma L. Reciprocal regulation of Hsa-miR-1 and long noncoding RNA MALAT1 promotes triple-negative breast cancer development. Tumour Biol. 2016;37:7383-94.

121. Lin A, Li C, Xing Z, Hu Q, Liang K, Han L, Wang C, Hawke DH, Wang S, Zhang Y, Wei Y, Ma G, Park PK, Zhou J, Zhou Y, Hu Z, Zhou Y, Marks JR,

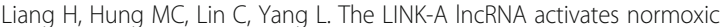
HIF1alpha signalling in triple-negative breast cancer. Nat Cell Biol. 2016;18: 213-24.

122. Abdul-Rahman U, Gyorffy B, Adams BD. linc00673 (ERRLR01) is a prognostic indicator of overall survival in breast cancer. Transcription. 2017:1-13.

123. Bamodu OA, Huang WC, Lee WH, Wu A, Wang LS, Hsiao M, Yeh CT, Chao TY. Aberrant KDM5B expression promotes aggressive breast cancer through MALAT1 overexpression and downregulation of hsa-miR-448. BMC Cancer. 2016;16:160

124. Corcoran DL, Pandit KV, Gordon B, Bhattacharjee A, Kaminski N, Benos PV. Features of mammalian microRNA promoters emerge from polymerase ॥ chromatin immunoprecipitation data. PLoS One. 2009;4:e5279.

125. Sossey-Alaoui K, Downs-Kelly E, Das M, Izem L, Tubbs R, Plow EF. WAVE3, an actin remodeling protein, is regulated by the metastasis suppressor microRNA, miR-31, during the invasion-metastasis cascade. Int J Cancer. 2011;129:1331-43.

126. Valastyan S, Reinhardt F, Benaich N, Calogrias D, Szasz AM, Wang ZC, Brock JE, Richardson AL, Weinberg RA. A pleiotropically acting microRNA, miR-31, inhibits breast cancer metastasis. Cell. 2009:137:1032-46.

127. Augoff K, McCue B, Plow EF, Sossey-Alaoui K. miR-31 and its host gene IncRNA LOC554202 are regulated by promoter hypermethylation in triplenegative breast cancer. Mol Cancer. 2012;11:5.

128. Xia Y, Xiao X, Deng X, Zhang F, Zhang X, Hu Q, Sheng W. Targeting long non-coding RNA ASBEL with oligonucleotide antagonist for breast cancer therapy. Biochem Biophys Res Commun. 2017;489:386-92.

129. Perou CM. Molecular stratification of triple-negative breast cancers. Oncologist. 2010;15(Suppl 5):39-48.

130. Lehmann BD, Bauer JA, Chen X, Sanders ME, Chakravarthy AB, Shyr Y, Pietenpol JA. Identification of human triple-negative breast cancer subtypes and preclinical models for selection of targeted therapies. J Clin Invest. 2011;121:2750-67

131. Schleidgen S, Klingler C, Bertram T, Rogowski WH, Marckmann G. What is personalized medicine: sharpening a vague term based on a systematic literature review. BMC Med Ethics. 2013:14:55.

132. Awada A, Vandone AM, Aftimos P. Personalized management of patients with solid cancers: moving from patient characteristics to tumor biology. Curr Opin Oncol. 2012;24:297-304.

133. Soudyab M, Iranpour M, Ghafouri-Fard S. The role of long non-coding RNAs in breast cancer. Arch Iranian Med. 2016;19:508-17.

134. Lv M, Xu P, Wu Y, Huang L, Li W, Lv S, Wu X, Zeng X, Shen R, Jia X, Yin Y, Gu $Y$, Yuan $H$, Xie $H$, Fu Z. LncRNAs as new biomarkers to differentiate triple negative breast cancer from non-triple negative breast cancer. Oncotarget. 2016:7:13047-59. 